WIKTOR KRAJNIAK

Zielona Góra

\title{
MIĘDZY MŁYNARSTWEM A ELEKTRYFIKACJA. SPOŁECZNO-GOSPODARCZE UWARUNKOWANIA WYKORZYSTANIA POTENCJAŁU ENERGETYCZNEGO RZEKI BÓBR OD ŚREDNIOWIECZA DO 1945 ROKU
}

Zarys treści: Artykuł przedstawia tradycje energetycznego wykorzystania rzeki Bóbr na przestrzeni XIII-XX w. Szczególną uwagę zwrócono na rolę młynów wodnych w procesie przemian cywilizacyjnych, poczynając od mechanizacji pracy w średniowiecznych warsztatach, przez rozwój przemysłu w okresie gospodarki folwarczno-pańszczyźnianej, kończąc na elektryfikacji przemysłu, rolnictwa i miast dzięki elektrowniom uruchamianym na bazie istniejaccych młynów wodnych. Do prześledzenia tej ewolucji posłużyły źródła archiwalne, lokalne kroniki i literatura przedmiotu. Dostarczyły one informacji dotyczacych uwarunkowań społecznych i czynników gospodarczych, które warunkowały ewolucję poszczególnych młynów we współczesne elektrownie bobrzańskie.

The content outline: The paper presents the tradition of the exploitation of the Bóbr River as a source of energy between the $13^{\text {th }}$ and the $20^{\text {th }}$ century. Particular focus is placed on the significance of water mills in the process of advancement of civilisation, starting from the mechanisation of production in medieval workshops, through industrial development in the era of manorial economy, down to the electrification of industry, agriculture, and towns thanks to power plants established on the basis of existent water mills. This process is traced with the use of archival sources, local chronicles, and secondary sources. They serve as the source of information on the social conditions and economic factors which influenced the evolution of individual mills into modern power plants on the Bóbr River.

Słowa kluczowe: rz. Bóbr, elektrownie wodne, elektryfikacja, energetyka wodna, industrializacja, młyny wodne

Keywords: the Bóbr, hydroelectric power plants, electrification, hydropower, industrialisation, water mills 


\section{Wstęp}

Potencjał energetyczny rzek jako istotny czynnik przemian cywilizacyjnych jest $\mathrm{w}$ polskiej historiografii niedoceniany. Nieliczne badania historyków ograniczały się do analizy pojedynczych epok, rzemiosł, zagadnień prawnych lub technologicznych ${ }^{1}$. Jedyną poważniejszą próba syntetycznego ujęcia tego zagadnienia na ziemiach polskich jest praca Bohdana Baranowskiego ${ }^{2}$. Praca ta jednak niewiele uwagi poświęca elementom łączącym dawne młyny wodne z powstałymi na ich bazie elektrowniami. Również w literaturze zagranicznej moment pojawienia się elektryczności wyznacza granicę rozdzielająca młyny wodne i elektrownie, jakby należały do jakościowo różnych rzeczywistości historycznych $^{3}$. Granica ta jest sztuczna, co jest szczególnie widoczne na przykładzie historii wykorzystania potencjału energetycznego mniejszych i średnich rzek, takich jak Bóbr.

Celem artykułu jest analiza głównych procesów społeczno-gospodarczych, które ukształtowały charakter energetyki wodnej w dorzeczu rzeki Bóbr. Ramy czasowe pracy wyznaczaja dwa ważne procesy modernizacyjne: kolonizacja niemiecka i proces powszechnej elektryfikacji. W okresie tym zmieniało się zastosowanie oraz wygląd samych młynów, które często padały ofiarą powodzi i pożarów, lecz zawsze odbudowywano je przy tym samym stopniu wodnym, na młynówce lub przy jazie, który piętrzył staw młyński. W ten sposób niektóre stopnie wodne piętrzyły wodę na potrzeby młynów, które

${ }^{1}$ M. Dembińska, Przetwórstwo zbożowe w średniowiecznej Polsce (X-XIV wiek), Wrocław-Warszawa-Kraków-Gdańsk, 1973; U. Sowina, Woda i ludzie w mieście późnośredniowiecznym $i$ wczesnonowożytnym, Warszawa 2009; H. Samsonowicz, Rzemiosło wiejskie $w$ Polsce XIV-XVI wieku, Warszawa 1954; S. Trawkowski, Młyny wodne w Polsce w XII wieku, KHKM, t. 7, 1959, nr 1; K. Buczek, Z dziejów mtynarstwa w Polsce średniowiecznej, „Studia Historyczne”, t. 12, 1969; K. Maleczyńska, Dzieje starego papiernictwa ślaskiego, Wrocław-Warszawa-Kraków 1961; Z. Kwaśny, Mtyny zbożowe $w$ dobrach Schaffgotschów na poczatku XVIII wieku „Śląski Kwartalnik Historyczny Sobótka” 1959, nr 4; W. Wasiutyński, Regal mtynny w średniowiecznym prawie polskim, Warszawa 1936; M. Frančić, Technika mtynów wodnych w Polsce w XVI i XVII w., KHKM, t. 2, 1954, nr 1-2; S. Januszewski, Elektrownie wodne doliny Bobru, w: Zabytki przemystu i techniki w Polsce, t. 6: Dzieła techniki - dobra kultury, red. S. Januszewski, Wrocław 2002.

${ }^{2}$ B. Baranowski, Polskie mtynarstwo, Wrocław-Warszawa-Kraków-Gdańsk 1977.

${ }^{3}$ Z ważniejszych prac warto wymienić: T. Reynolds, Stronger than a Hundred Men. A History of the Vertical Water Wheel, Baltimore-London 1983; T.P. Hughes, Networks of Power. Electrification in Western Society 1880-1930, Baltimore 1983. 
w kolejnych wiekach zasilały warsztaty rzemieślnicze, manufaktury i pierwsze fabryki.

Ze względu na rozległa perspektywę czasową pracy określono jedynie główne trendy rozwojowe na przykładzie poszczególnych stopni wodnych, które były najczęściej wzmiankowane w źródłach archiwalnych, lokalnych kronikach i literaturze przedmiotu. Różnorodność wykorzystanych materiałów w postaci dokumentów lokacyjnych miast czy statutów spółek elektryfikacyjnych nie pozwala na pełne przytoczenie tu i omówienie bazy źródłowej. Jej szczegółowy wykaz znajduje się w przypisach i na końcu opracowania.

\section{Średniowiecze}

Podstawa energetyki wodnej w wiekach średnich były młyny wodne z pionowym kołem wodnym, określane mianem młyna rzymskiego lub młyna Witruwiusza, który jako pierwszy opisał zasadę działania takiego koła ${ }^{4}$.

Kiedy młyny typu rzymskiego pojawiły się na ziemiach polskich? Problem ten nadal wywołuje wiele kontrowersji i polemik w polskiej historiografii. Niektórzy autorzy, przeceniając poziom rozwoju cywilizacyjnego ziem polskich, jego początków doszukiwali się na przełomie XI i XII w. ${ }^{5}$ Większość badaczy przesuwa ten moment na XIII w. ${ }^{6} \mathrm{Na}$ rzece Bóbr pierwsze wzmianki o młynach wodnych pochodzą z początków XIII w., gdy Henryk Brodaty sprowadzał pierwszych osadników z Europy Zachodniej.

Próbując ustalić czynniki warunkujące energetyczne wykorzystanie rzeki Bóbr w epoce średniowiecza, należy w pierwszej kolejności odtworzyć warunki początkowe, czyli uwarunkowania społeczno-gospodarcze, jakie wykształciły się w przeciagu XIII w. Istotne jest zwłaszcza ustalenie, kto w tym czasie dysponował odpowiednim zapleczem, pozwalającym na budowę młyna wodnego, który był jednym z najdroższych warsztatów pracy. Według szacunków Stanisława Trawkowskiego koszty jego budowy mogły wynosić wówczas 26 grzywien czystego srebra, co stanowiło równowartość znaczniejszej wsi ${ }^{7}$. Oprócz wysokich kosztów budowy kolejną barierą były obostrzenia prawne, związane

\footnotetext{
${ }^{4}$ Witruwiusz, $O$ architekturze ksiag dziesięć, Warszawa 1999, s. 240-241.

${ }^{5}$ S. Trawkowski, dz. cyt., s. 74.

${ }^{6}$ K. Buczek, dz. cyt., s. 27; M. Dembińska, dz. cyt., s. 63-67.

${ }^{7}$ S. Trawkowski, dz. cyt., s. 78.
} 
z tzw. regale młyńskim, które na omawianym obszarze niemiecka historiografia przypisywała książętom śląskim ${ }^{8}$. To oni przydzielali biskupom, rycerzom, zasadźcom zarówno prawo połowu ryb w rzece, jak i przegradzania jej jazami i budowy młynów na podstawie jednostkowych zezwoleń zawartych najczęściej w dokumentach fundacyjnych i lokacyjnych ${ }^{9}$.

Przywilej młyński przypisany był do nadawanej ziemi. Po jej uzyskaniu od księcia, właściciel ziemi, np. biskup, mógł zezwalać na budowę młynów sołtysom zakładanych wówczas wsi. Komu najczęściej udzielano przywileju wybudowania młyna? Według Marii Dembińskiej w XIII w. wśród wzmianek źródłowych o nadaniu młyna lub przywileju jego wybudowania dominujaca grupę na Ślasku stanowiły klasztory i kościoły (47\%) oraz wójtowie miejscy, sołtysi i dzierżawcy młynarze (45\%). Resztę stanowiły przywileje nadane biskupom $(4 \%)$ i rycerzom $(2 \%)^{10}$. Dane te odnoszą się do młynów zbożowych, lecz można je uznać za reprezentacyjne dla całego młynarstwa, gdyż w średniowieczu osobne młyny rzemieślnicze były rzadkością, a najczęstszą praktyką było montowanie przy młynie zbożowym dodatkowego koła wodnego dla zasilania folusza czy kamienia szlifierskiego.

Dlaczego te dwie grupy miały największy wpływ na rozwój młynarstwa wodnego? W XIII w. dorzecze rzeki Bóbr było słabo zaludnionymi peryferiami zachodniego Ślaska. Inicjatorem kolonizacji tego obszaru był Henryk Brodaty, dążacy do rozwoju osadnictwa obszarów granicznych. Również jego następcy, którzy w wyniku postępującego rozbicia dzielnicowego dysponowali coraz mniejszymi księstwami, dążyli do intensyfikacji życia gospodarczego poprzez wzrost wydajności eksploatacji ziem, lasów i rzek, co miało zapewnić większe wpływy z danin. Nadawali wiec ziemię klasztorom i zasadźcom, którzy mieli sprowadzić osadników do nowych osad ${ }^{11}$.

Przegląd średniowiecznego młynarstwa warto zacząc od instytucji kościelnych, które procentowo otrzymały na Śląsku najwięcej nadań przywileju młyńskiego. W powszechnej opinii klasztory były krzewicielami wyższej kultury rolnej i rzemieślniczej. Zwłaszcza cystersom

${ }^{8}$ G.A. Tschoppe, G.A. Stenzel, Urkundensammlung zur Geschichte des Ursprungs der Städte und der Einführung und Verbreitung deutscher Kolonisten und Rechte in Schlesien und der Ober-Lausitz, Hamburg 1832, s. 8.

9 Tamże, s. 3-4, 8-9.

${ }_{10}$ M. Dembińska, dz. cyt., s. 81.

${ }_{11}$ W. Wereszczyński, Powstanie i lokacja Jeleniej Góry na prawie miejski, „Rocznik Jeleniogórski”, t. 40, 2008, s. 50-51. 
przypisywano wielkie zasługi w dziedzinie rozwoju młynarstwa ${ }^{12}$. Istotnie, książęta śląscy upatrywali w zakonach instytucji, które mogłyby przyczynić się do rozkwitu gospodarczego ich terytoriów. W $1217 \mathrm{r}$. Henryk Brodaty sprowadził do Nowogrodu Bobrzańskiego augustianów, nadając im podstawę materialną do prowadzenia akcji kolonizacyjnej w postaci wsi Popowice i 120 łanów lasu. W akcie fundacyjnym znalazł się także zapis o uprawnianiach do połowu ryb i stawiania młynów wodnych nad Bobrem ${ }^{13}$. Czy augustianie od razu skorzystali z tego prawa i wybudowali młyn na rzece? Z braku źródeł nie można tego stwierdzić jednoznacznie. Pierwsza wzmianka o młynie klasztornym pochodzi dopiero z 1353 r. Ówczesny dokument informował, że właściciel Nowogrodu Ulryk von Pack podarował Teodorykowi, opatowi augustianów, młyn dwukołowy nad Bobrem powyżej jazu naprzeciw starego młyna w Nowogrodzie ${ }^{14}$. Nie wiadomo, kiedy powstał ów stary młyn. Wiadomo tylko, że należał do augustianów, bowiem kronikarz augustiański podaje, że do folwarku klasztornego w Nowogrodzie przynależały dwa młyny wodne zlokalizowane na dwóch brzegach rzeki ${ }^{15}$.

Wspieranie nowej fundacji kontynuowali następcy Brodatego. W 1245 r. Bolesław Rogatka podarował augustianom wieś Dobroszów Wielki koło Nowogrodu Bobrzańskiego i wszystkie zyski z bartnictwa i tamtejszych młynów ${ }^{16}$. W górnym biegu rzeki Bóbr, który był wówczas obszarem słabo zaludnionym, Bolesław Rogatka, wypełniając wolę zmarłej żony, sprowadził w 1261 r. do Cieplic augustianów, nadając im jedną wieś Malinnik z 50 łanami ziemi i 200 łanów lasu pod zasiedlenie, licząc na zaradność zakonników w zagospodarowaniu terenu ${ }^{17}$.

Fundacje klasztorne w pierwszym okresie kolonizacji dorzecza Bobru wykazywały się dużą niestałościa. Augustianie z Nowogrodu Bobrzańskiego nie mieli najwyraźniej ochoty rozwijać życia gospodarczego na leśnym pustkowiu, gdyż chętnie przystali na propozycję przenosin do Żagania, który był wówczas prężnym ośrodkiem lokalnego

${ }^{12}$ Ch. Kouschil, Mtynarstwo a rozwój społeczny w średniowieczu, w: Niebezpieczne drogi i podejrzani mtynarze, przeł. Z. Czarnuch, Gorzów Wielkopolski 2000, s. 118; R. Kubicki, Sieć młynów wodnych w dobrach klasztornych na Pomorzu Wschodnim w XIII-XVI w., „Hereditas Monasteriorum”, t. 2, 2013, s. 38.

${ }^{13}$ Codex Diplomaticus Silesiae (dalej: CDS), t. 7, cz. 1, s. 113.

${ }_{14}$ A. Heinrich, Geschichtliche Nachrichten über Naumburg am Bober, Freiwaldau und Halbau aus den Quellen zusammengestellt, Sagan 1900, s. 7.

15 J. Dlugos, Chronik der Propstei Naumburg am Bober, Grünberg 1926, s. 13.

16 CDS, t. 7, cz. 1, s. 284.

${ }^{17}$ W. Wereszczyński, dz. cyt., s. 50-51. 
handlu i rzemiosła ${ }^{18}$. Podobnie augustianie z Cieplic, którym nadano pustki leśne celem przeprowadzenia tam akcji kolonizacyjnej, szybko opuścili Cieplice w poszukiwaniu lepszej lokalizacji. Roman Stelmach podaje, że na miejsce augustianów syn Bolesława Rogatki książę lwówecki Bernard Zwinny sprowadził do Cieplic joannitów. Nadał im podobny majątek i zwolnił od posług prawa książęcego na 20 lat. Jednak i joannici wynieśli się stąd po 10 latach $^{19}$. Dopiero w 1403 r. w Cieplicach na stale osiedli cystersi, których sprowadził lokalny rycerz Gotsche Schoff, nadajac im folwark w Cieplicach, młyn trzykołowy w Malinniku, a także wieś Wojcieszyce z kościołem i karczmą oraz prawo wyższego i niższego sądownictwa ${ }^{20}$. W 1416 r. ten sam rycerz przekazał ufundowanej przez siebie prepozyturze w Cieplicach 8 małdratów słodu ze swego młyna zlokalizowanego przed Jelenią Górą na rzece Kamienna i 6 małdratów słodu z młyna przy swojej rezydencji w Cieplicach ${ }^{21}$.

Podobna niechęć rozwijania życia gospodarczego od podstaw charakteryzowała też inne zgromadzenia zakonne. W 1249 r. Bolesław Rogatka nadał benedyktynom z Krzeszowa osadę targową Kamienna Góra, położona w widłach Zadrny i Bobru, zezwalając na jej rozbudowę na prawie niemieckim ${ }^{22}$. Jednak Bolesław Rogatka i tu niewiele zyskał na współpracy z zakonami, gdyż benedyktyni nie byli zainteresowani rozwijaniem osady, utrzymując w swojej własności osadę targowa w takim kształcie, w jakim ją uzyskali. Niezadowoleni prawdopodobnie $\mathrm{z}$ lokalizacji swej fundacji $\mathrm{w}$ słabo zaludnionej i niezagospodarowanej okolicy, jakiś czas później wynieśli się stamtąd. Na ich miejsce Bolko Surowy sprowadził w 1292 r. cystersów. To zgromadzenie zostało w Krzeszowie na stałe, gdyż zostało sowicie uposażone przez fundatora licznymi ławami chlebowymi i jatkami mięsnymi w okolicznych osadach. W samej Kamiennej Górze cystersi posiadali młyny i słodownię oraz prawo połowu ryb ${ }^{23}$.

18 A. Pobóg-Lenartowicz, Kanonicy regularni a miasto na przykładzie Żagania, w: Klasztor w mieście średniowiecznym i nowożytnym, red. M. Derwich, A. Pobóg-Lenartowicz, Wrocław-Opole 2000, s. 383-385.

${ }^{19}$ R. Stelmach, Cieplice $w$ XIII $w$. - nieudane fundacje augustiańska i joannicka, „Rocznik Jeleniogórski”, t. 32, 2000, s. 55.

${ }^{20}$ Tenże, Poczatki prepozytury cystersów krzeszowskich w cieplicach, „Rocznik Jeleniogórski”, t. 34, 2002, s. 77.

${ }^{21}$ Tamże, s. 78-79.

${ }^{22}$ CDS, t. 7, cz. 1 , s. 305.

${ }^{23}$ R. Stelmach, Posiadłości klasztoru krzeszowskiego $w$ miastach ślaskich na podstawie zachowanych dokumentów w Archiwum Państwowym we Wroctawiu, w: Klasztor w mieście..., s. 118-121. 
W proces rozwoju energetyki wodnej w dorzeczu Bobru klasztory włączyły się intensywniej dopiero w XIV w., gdy kwitnące życie gospodarcze na kolonizowanym terenie, przyczyniło się do wzrostu zamożności mieszkańców i w efekcie również lokalnych instytucji kościelnych. Pierwsze wzmianki o młynach wybudowanych z inicjatywy zgromadzeń pojawiaja się dopiero pod koniec XIII w. Dokument z 1298 r. informuje, że w Lubomierzu przełożona benedyktynek Katarzyna po założeniu klasztoru wybudowała młyn słodowy ${ }^{24}$. Jednak w posiadanie młynów klasztory nad Bobrem najczęściej wchodziły w wyniku zakupu lub nadania. W 1307 r. rodzina rycerska Liebenthal hojnie obdarowała klasztor, przekazując mu wieś Lubomierz, a także wsie Radoniów, Mojesz, Milęcice z dwoma folwarkami oraz wieś Oleszna Pogórska z kościołem i młynem ${ }^{25}$.

Również pozostałe klasztory fundowane nad Bobrem nabywały młyny dopiero wraz z rozwojem ich bazy materialnej. Znamienny jest przykład magdalenek z Nowogrodźca. W 1217 r. Henryk Brodaty wraz ze swoją żona św. Jadwiga ufundowali żeński klasztor, któremu - podobnie jak innym fundacjom na tym terenie - przekazali w uposażeniu dochody tylko z jednej wsi: Łagów koło Zgorzelca. Dopiero w połowie XIII w. magdalenki otrzymały kolejne darowizny w postaci dziesięciny z Uniegoszczy, 12 łanów ziemi w Kierznie i dochody z ceł w Bolesławcu ${ }^{26}$. Liczne donacje nadawane przez kolejnych Piastów ślaskich z linii legnickiej, głogowskiej i świdnicko-jaworskiej umożliwiły klasztorowi inwestycje w młyny wodne. Dokument z 1310 r. informuje, iż panowie Frizcho, Wilcyrius i Peter sprzedali klasztorowi magdalenek w Nowogrodźcu dwa młyny w dorzeczu Bobru wraz z prawem monopolu młyńskiego w okolicy ${ }^{27}$.

Również w dolnym biegu rzeki Bóbr wzmianki o młynach klasztornych pochodza głównie z XIV w. W 1307 r. rycerz Heinrich von Kythelicz przekazał $\mathrm{w}$ testamencie augustianom żagańskim swój młyn na Czernej, dopływie Bobru' ${ }^{28}$. W 1356 r. augustianie zakupili wieś Moczyń i w jej pobliżu postawili swój młyn ${ }^{29}$. W samym Żaganiu augustianie

${ }^{24}$ CDS, t. 7, cz. 3, s. 255.

${ }_{25}$ R. Stelmach, Dokumenty do dziejów klasztoru benedyktynek w Lubomierzu, „Rocznik Jeleniogórski”, t. 37, 2005, s. 123.

${ }^{26}$ Tenże, Dzieje klasztoru Magdalenek w Nowogrodźcu nad Kwisq w świetle zachowanych dokumentów, „Rocznik Jeleniogórski”, t. 30, 1998, s. 99, 103-104.

${ }^{27}$ CDS, t. 16, s. 179.

${ }^{28}$ A. Heinrich, Geschichte der Fürstentums Sagan bis zum Ende der säschischen Herrschaft im Jahre 1549, Sagan 1911, s. 689.

${ }^{29}$ Tamże. 
weszli w posiadanie młyna w 1334 r. Wówczas to książę Henryk IV Wierny sprzedał opatowi Trudwinowi młyn dolny, który zlokalizowany był na młynówce przy bramie żarskiej ${ }^{30}$. Bracia nie cieszyli się długo nowym nabytkiem. Kronikarz Żagania Artur Heinrich podaje, że niedługo później następca księcia zaczął nalegać na zwrot młyna. Gdy zakonnicy odmówili, książę uwięził dwóch przedstawicieli zgromadzenia i zagroził ścięciem ich głów, jeśli zakon nie potwierdzi darowizny młyna na rzecz księcia. Ostatecznie książę odzyskał młyn, oddając jednak zakonnikom cenę jego zakupu ${ }^{31}$.

Przegląd najważniejszych fundacji klasztornych i wzmianek o należących do nich młynach wskazuje, że w XIII w. zgromadzenia zakonne nie przyczyniły się wydatnie do rozwoju energetyki wodnej na Bobrze. $\mathrm{Na}$ omawianym terenie ich uposażenia były niezwykle skromne. Wspomniane zgromadzenia w Nowogrodzie, Nowogrodźcu czy Cieplicach otrzymały po jednej wsi i ogromne połacie niezamieszkanych lasów, co przy kosztach budowy młyna porównywalnych z wartością znaczniejszej wsi powodowało, że w XIII w. tego typu inwestycje były rzadkością. Dlatego też klasztory w dorzeczu Bobru budowę swych młynów rozpoczynały głównie w XIV w., gdy w wyniku kolejnych nadań książęcych i innych darczyńców ich baza materialna była na tyle solidna, iż mogły sobie pozwolić na tego typu inwestycje, a wzrost liczby ludności na kolonizowanym obszarze zapewniał im rentowność.

Zmniejszenie kosztów budowy młyna możliwe było dopiero wówczas, gdy nad Bóbr przybywały kolejne fale osadników a wśród nich duża liczba wykwalifikowanych cieśli, znających się na sztuce budowy młynów i jazów. Nowo przybyli rzemieślnicy w większości osiadali w intensywnie lokowanych wówczas miastach, które stawały się miejscem koncentracji ludności oraz lokalnego handlu i rzemiosła. W większości przypadków lokacji miast i osad z XIII w., w ich dokumentach lokacyjnych znajdował się zapis o możliwości budowy młynów wodnych nad Bobrem lub nad jego dopływami.

Henryk Brodaty upatrywał w miastach ośrodków wzrostu, dlatego już w $1211 \mathrm{r}$. sprowadził sobie z Magdeburga odpis prawa samorządowego, zawierającego pouczenie o młynach miejskich: ius molendini ${ }^{32}$. Maria Dembińska podaje, że wśród nadań i pozwoleń na budowę młyna na Ślasku 45\% wzmianek źródłowych odnosiło się do wójtów i sołtysów ${ }^{33}$.

\footnotetext{
${ }^{30}$ CDS, t. 29, s. 11.

31 A. Heinrich, Geschichte der Fürstentums..., s. 689.

${ }_{32}$ M. Dembińska, dz. cyt., s. 83.

${ }^{33}$ Tamże, s. 81.
} 
Zajmowali się oni głównie sądownictwem. Dbali też o interesy właściciela ziemi, ściagając podatki i czynsz. Oprócz mocnej pozycji prawnej wójtowie lokowanych miast mieli znaczne przywileje ekonomiczne. Mogli posiadać ławy chlebowe, szewskie i jatki mięsne oraz łany ziemi wolne od czynszu. Mogli także budować tzw. młyny wójtowskie. Liczbę takich młynów określał dokument lokacyjny. Na przykład wójt dziedziczny Szprotawy mógł posiadać tylko jeden młyn, a wójt Themo z Nowogrodźca mógł mieć już dwa młyny. Zachęta do ich budowy miała być dziedziczność wójtostwa, także w linii żeńskiej. Z dziedzicznościa wójtostwa wiązała się także dziedziczność prawa do korzystania z rzeki i dziedziczność monopoli młyńskich ${ }^{34}$.

W jaki sposób mocna pozycja prawna i ekonomiczna wójtów przełożyła się na ich wkład w rozwój młynarstwa wodnego nad Bobrem? W świetle zachowanych źródeł jednym z najstarszych miast lokowanych w dorzeczu Bobru jest Wleń. Prawa miejskie otrzymał od Henryka Brodatego w 1214 r., a już w 1217 r. pojawia się informacja o czynszu płaconym $\mathrm{z}$ młyna ${ }^{35}$. Bliższe informacje o młynach $\mathrm{w}$ mieście pochodza z XIV w. W 1345 r. książę Henryk Jaworski sprzedał młyn dolny, przy którym znajdował się również folusz, wraz z wszystkimi prawami przypisanymi do młyna wójtowi dziedzicznemu Wlenia ${ }^{36}$. Drugi młyn we Wleniu kupiła już rada miejska w 1442 r. Był to młyn górny leżący nad rzeką Bóbr w miejscowości Nielestno ${ }^{37}$.

Miasta, podobnie jak klasztory w XIII w., dopiero budowały swa pozycję ekonomiczna, dlatego też większość wzmianek o młynach miejskich pochodzi również z XIV w. Wraz z bogaceniem się mieszczan ośrodki miejskie uniezależniały się spod władzy książąt, poprzez wykup urzędu wójtowskiego i ustanowienie w jego miejsce rad miejskich. W miastach lokowanych nad Bobrem proces ten zapoczątkowany został XIV w., co było skutkiem wzrostu ich zamożności i pozycji gospodarczej. Spore dochody, uzyskiwane m.in. z młynów wodnych, zapewniały tworzącym się samorządom miejskim niezależność ekonomiczna.

Znamienny jest przypadek Jeleniej Góry, gdzie mieszczanie na przestrzeni XIV w. zdobywali kolejne przywileje ekonomiczne związane z wyrobem sukna, posiadaniem ław chlebowych, szewskich i jatek mięsnych W 1348 r. Bolko II Mały nadał miastu prawo mili, rozciagając

${ }^{34}$ G.A. Tschoppe, G.A. Stenzel, dz. cyt., s. 182-185.

35 A. Knoblich, Chronik von Lähn und Burg Länhaus am Bober. Urkundliche Beiträge zur Geschichte der Städte, Ritterburgen, Fürsten, und Adelsgeschlechter Schleseins, Breslau 1863, s. 21.

36 Tamże, s. 85.

37 Tamże. 
ekonomiczne wpływy miasta na cały okręg. W kolejnych latach miasto zyskiwało kolejne uprawnienia ekonomiczne, jak monopol produkcji słodu, uprawnienia górnicze i prawo bicia monety ${ }^{38}$. Wzbogaceni kupcy i rzemieślnicy jeleniogórscy wykupili urząd wójta dziedzicznego w 1374 r. od księżnej Agnieszki ${ }^{39}$. Po tym fakcie miasto stało się właścicielem młynów wójtowskich w mieście wraz z przynależnymi do nich monopolami i jednocześnie właścicielem przypisanego do urzędu wójtowskiego dziedzicznego prawa budowy młynów na tym odcinku rzeki.

W tym samym czasie rada miejska, budujac baze materialna pod niezależność ekonomiczną tworzącego się samorządu, wykupiła największy w mieście młyn sześciokołowy, wybudowany w 1299 r. u stóp wzgórza zamkowego przez Zygfryda z Wojanowa. Po jego śmierci młyn odziedziczyły cztery osoby. Niecały wiek później właścicielem młyna było już miasto, które odkupiło prawo do niego od wszystkich czterech właścicieli ${ }^{40}$. Prawa ostatniego współwłaściciela miasto wykupiło 30 kwietnia 1391 r. Wówczas księżna Agnieszka potwierdziła, że Gotsche Schoff sprzedał radzie miejskiej czwartą część młyna ${ }^{41}$.

Cesja dziedzicznych praw wójta na radę miejską Jeleniej Góry doprowadziła w 1405 r. do sporu z lokalnym rycerstwem. Wówczas Fritz Lother, właściciel majątku w miejscowości Garbary, płożononego w górę rzeki Bóbr, bez zgody miasta wybudował jaz, który spiętrzył nowy staw, czyniąc to bez porozumienia z miastem, przez co mogły ucierpieć położone w dół rzeki młyny miejskie - zwłaszcza zlokalizowane na Bobrze - młyny górny i dolny. Do rozwiązania sporu zaangażowano aż 23 osoby, głównie lokalnego rycerstwa i mieszczan ${ }^{42}$. Rada miejska, chcąc uniknąć w przyszłości podobnych sporów, dążyła do pisemnego potwierdzenia, iż po wykupie wójtostwa jest jedynym podmiotem władnym do decydowania o budowie jazów na tym odcinku rzeki, otrzymując $\mathrm{w}$ tym samym roku takie potwierdzenie na mocy przywileju królewskiego ${ }^{43}$.

${ }^{38}$ W. Szczerepa, Zarys historii Jeleniej Góry od XIV do XX wieku, w: Z historii Jeleniej Góry i regionu, red. K. Kułakowska, Jelenia Góra 2012, s. 50-52.

${ }^{39}$ R. Stelmach, Archiwum dokumentów miasta Jeleniej Góry, „Rocznik Jeleniogórski”, t. 40, 2008, s. 88.

${ }^{40}$ J.K. Herbst, Chronik der Stadt Hirschberg in Schlesien bis zum jahre 1847, Hirschberg 1849, s. 30.

${ }^{41}$ R. Stelmach, Dokumenty ksiażat świdnickich (dotyczqce osób i instytucji z terenu dawnego księstwa jaworskiego) zachowane $w$ zbiorach archiwalnych, „Rocznik Jeleniogórski”, t. 39, 2007, s. 34.

${ }^{42}$ J.K. Herbst, dz. cyt., s. 38.

${ }^{43}$ L. Żuk, Z dziejów miasta Jelenia Góra. Mons Cervi - Hirschberg, Jelenia Góra 2013, s. 72 . 
Podobna ewolucja młynów wójtowskich w młyny miejskie dokonała się w Szprotawie, położonej w środkowym biegu rzeki Bóbr. Potwierdza to dokument z 1304 r., w którym Konrad II Głogowski odnowił przywilej lokacyjny dla Szprotawy. W akcie tym Konrad II na prośbę miasta, które w pożarze w 1260 r. straciło część zabudowy, potwierdził uprawnienia miasta do budowy młynów na rzece Bóbr i jego dopływie Szprotawie $^{44}$. Odnowienie dokumentu lokacyjnego Szprotawy miało miejsce na prośbę szprotawskich mieszczan. Być może chcieli w ten sposób potwierdzić swoje przywileje ekonomiczne po ukonstytuowaniu się samorządu. W Szprotawie, podobnie jak w innych miastach nad Bobrem, rada miejska wykupywała źródła dochodów dla umocowania miejskiej samorządności. Z byłych dóbr książęcych zarządzanych przez wójta w samej Szprotawie książę pozostawił sobie zamek, okoliczne dobra i prawo połowu ryb na Bobrze ${ }^{45}$. W 1396 r. Henryk VII Rumpold sprzedał radzie miejskiej folwark, który dawniej należał do kolejnych wójtów Hentschela i Gregora. Książę pozostawił sobie i swoim następcom prawo do otrzymywania darmowego drewna $\mathrm{z}$ folwarku na konserwację i rozbudowę swoich młynów i jazów ${ }^{46}$.

Młynarstwo wodne rozwijało się w tym okresie również na terenach wiejskich, gdzie młyny wodne najczęściej powstawały w dobrach rycerskich. Najwięcej nadań ziemskich rycerze otrzymali na Ślasku po bitwie z Tatarami pod Legnica w 1241 r., gdy zginęło wielu ślaskich rycerzy. $\mathrm{Na}$ ich miejsce książęta ślasscy sprowadzali rycerzy z przeludnionej Europy Zachodniej, gdzie nie mieli szans na dziedziczenie majątków rodzinnych, a ruch krucjatowy powoli wygasał. Przybysze, gromadząc wielkie majątki na wschodzie, wypierali miejscowe rycerstwo i stawali się w kolejnych wiekach lokalną arystokracja. W okresie średniowiecza ta grupa społeczna nie odegrała większej roli w rozwoju energetyki wodnej na Bobrem, na co wskazuje niewielka liczba przywilejów na budowę młyna w dobrach rycerskich $2 \%{ }^{47}$. Dopiero w XVI w. rodzinom Kietlicz, Promnitz, Liebenthal czy Schaffgotsch udało się zgromadzić znaczniejsze majątki. Ta ostatnia rodzina, której początek dał rycerz Gotsche II Schoff, w kolejnych wiekach zgromadziła spore posiadłości ziemskie z wieloma młynami wodnymi ${ }^{48}$.

${ }^{44}$ CDS, t. 31, s. 15 .

45 Tamże, s. 64-66.

${ }^{46}$ CDS, t. 31, s. 17.

${ }^{47}$ M. Dembińska, dz. cyt., s. 81.

${ }^{48}$ W. Wereszczyński, Proces rozbudowy majatku Gotsche II Schoffa, założyciela rodu z Chojnika i Gryfa, cz. 2, „Rocznik Jeleniogórski”, t. 35, 2003, s. 41-154. 


\section{Epoka nowożytna}

Wiek XIV i XV przyniósł ogólny kryzys gospodarczy związany z załamaniem się koniunktury napędzanej przez kolonizację. Formuła feudalizmu, w miarę wyzbywania się przez feudałów areałów wolnej i niezagospodarowanej ziemi, powoli się wyczerpywała. Na kurczacym się rynku o źródła dochodów musiały ze sobą rywalizować poszczególne warstwy ówczesnego społeczeństwa. By utrzymać swą pozycję ekonomiczna, miasta, rycerstwo i klasztory musiały konsekwentnie pilnować swoich przywilejów i ściagać ustalone wcześniej należności. Rodziło to konflikty, jak na przykład spory książąt z opatami klasztoru w Żaganiu o młyn dolny ${ }^{49}$ czy konflikt rady miejskiej Jeleniej Góry z Fritzem Lotherem.

W miarę intensyfikacji gospodarki towarowo-pieniężnej w dorzeczu rzeki Bóbr, system ekonomiki feudalnej ustępował miejsca rodzącemu się powoli kapitalizmowi, w którym głównymi ośrodkami wzrostu były bogacące się miasta, które podczas lokacji na prawie magdeburskim zyskały mocną pozycję prawną i ekonomiczna, ugruntowaną w XVI w.

Po przejęciu młynów rady miejskie skrupulatnie rozbudowywały swe młyny o kolejne koła wodne, które dzierżawiły lokalnym rzemieślnikom. W jaki sposób miasta pozyskiwały własne młyny w epoce nowożytnej? Najczęściej rady miejskie decydowały się na kupno całego młyna od dotychczasowego właściciela lub nabycie praw do części młyna poprzez udział w kosztach jego odbudowy po pożarze lub powodzi. W przypadku młynów wójtowskich stawały się one własnościa rady miejskiej po wykupie przez mieszczan urzędu wójtowskiego, co następowało już XIV, a w przypadku mniejszych ośrodków w XV i XVI w.

W Kamiennej Górze, która stanowiła uposażenie cystersów z pobliskiego Krzeszowa, urząd wójtowski, dajacy klasztorowi m.in. prawo połowu ryb w rzece i budowy młynów, piastował opat. Było to przyczyna licznych zatargów z mieszczanami, szukajacymi dla siebie nowych źródeł dochodów. Spory między klasztorem a miastem wybuchały w latach 1399, 1409 i 1458 i zawsze były rozstrzygane na korzyść klasztoru z faktu posiadania przez opata dziedzicznego urzędu wójtowskiego ${ }^{50}$.

Mieszczanie zyskali mocniejszą pozycję w mieście dopiero w $1527 \mathrm{r}$. w wyniku rozwijającej się reformacji. Wówczas opat cystersów sprzedał miastu wójtostwo i wieś Ptaszków ${ }^{51}$. W tym czasie w mieście znajdowały

${ }^{49}$ A. Pobóg-Lenartowicz, dz. cyt., s. 390.

${ }^{50}$ R. Stelmach, Posiadłości klasztoru krzeszowskiego..., s. 119.

51 W. Perschke, Beschreibung und Geschichte der Stadt Landeshut in Schlesien als Beitrag zur Verfassung-Geschichte deutscher Städte, Landeshut 1829, s. 45. 
się trzy młyny: zbożowy, zwany młynem wielkim, i młyn foluszniczy, a na dopływie Bobru, Zadrnie, młyn miejski ${ }^{52}$. Po przejęciu pełni władzy samorządowej nad miastem i okolica, rada miejska zarządziła, że mieszkańcy miasta i pobliskiej wsi Ptaszków mają mielić swoje zboże w młynie wielkim. Dodatkowo na mieszkańców Ptaszkowa nałożono obowiązek dostarczania drewna na konserwację i utrzymanie młynówki oraz jazu piętrzącego ${ }^{53}$.

Najwięcej wzmianek o młynach w dorzeczu Bobru pochodzi z Bolesławca, który w XV w. stał się prężnym ośrodkiem gospodarczym. W mieście funkcjonowały nadal dawne młyny. Młyn na piasku, należał początkowo do zamku, a od $1260 \mathrm{r}$. do szpitala prowadzonego przez krzyżowców z czerwona gwiazda. W 1568 r. młyn został przejęty przez miasto razem ze szpitalem ${ }^{54}$.

Według kroniki miasta młyn dominikański w 1410 r. należał jeszcze do zakonu dominikanów ${ }^{55}$. Miasto stało się jego właścicielem w 1524 r., gdy mieszkańcy miasta przyjęli wiarę ewangelicka, a zakonnicy uciekli z miasta. W 1668 r. dominikanie wrócili do Bolesławca i odzyskali młyn od miasta, w wyniku akcji rewindykacyjnej prowadzonej przez katolickich Habsburgów po wojnie trzydziestoletniej. Młyn posiadał wówczas dwa koła mielace zboże. W 1689 r. jedno koło wodne wydzierżawiono dziewiarzowi, który wykorzystał je do zasilania folusza z trzema stęporami. Umowę dzierżawy odnowiono w 1722 r. W 1761 r. ówczesnemu właścicielowi zakładu dziewiarskiego sprzedano działkę przy młynie pod rozbudowę zakładu, w którym wyrabiano także pończochy ${ }^{56}$.

Dobra, które nie zostały wykupione przez miasta, nadal pozostawały własnością aktualnego władcy. W Bolesławcu do dóbr lennych należał pochodzący z XIV w. młyn górny, należący do folwarku zamkowego. W 1502 r. młyn został rozbudowany. Posiadał pięć kół wodnych, z czego cztery służyły do mielenia zboża i słodu ${ }^{57}$. Od $1527 \mathrm{r}$. dochody z młyna górnego zasilały skarb cesarski, bowiem od tego roku Ślask, a wraz z nim obszar dorzecza Bobru, przeszły pod panowanie Habsburgów.

52 Tamże, s. 114.

${ }^{53}$ E. Kunick, Heimatbuch des Kresises Landeshut in Schlesiens, t. 1, Landeshut 1929, s. 141.

${ }^{54}$ J.G. Bergemann, Chronik der Stadt Bunzlau. Erste Abtheilung, Bunzlau 1829, s. 46.

55 E. Wernicke, Chronik der Stadt Bunzlau von den Altesten Zeiten bis zur Gegenwart, Bunzlau 1884, s. 23.

${ }^{56}$ J.G. Bergemann, dz. cyt., s. 46-47.

57 E. Wernicke, dz. cyt., s. 50. 
W 1544 r. przy młynie górnym pojawiło się kolejne koło wodne służące do mielenia kory dębowej, dzierżawione lokalnym szewcom ${ }^{58}$.

Po koniec XVI w. cesarz Rudolf II rozpoczał wyprzedawanie swych dóbr w związku z potrzebą sfinansowania III wojny austriacko-tureckiej. Dzięki temu młyn górny zakupiła w 1594 r. rada miejska, która przystapiła do jego rozbudowy. W 1602 r. jedno z kół wodnych zaczęło zasilać zlokalizowany tam tartak. W 1692 r. koło wodne przy młynie zaczęli dzierżawić również białoskórnicy. W 1750 r. młyn znacznie się rozrósł, gdyż koła wodne były dzierżawione stolarzowi, który przy młynie prowadził tartak. W początkach XVIII w. przy tym samym jazie piętrzącym, po drugiej stronie rzeki, znajdowały się także młyn mielący korę dębowa, folusz, młyn białoskórniczy i tartak. Młyn górny funkcjonował jako młyn miejski aż do roku 1813, gdy potomek młynarza Friedrich Gläser wykupił od miasta cały młyn na własnośćc ${ }^{59}$. Poniżej młyna górnego znajdował się młyn dolny. Podczas wojny trzydziestoletniej młyn został splądrowany. Kolejni młynarze dzierżawili młyn w 1750 i 1765 r. ${ }^{60}$ Młyn dolny został sprzedany przez miasto w 1825 r. na rzecz Gottlieba Schmidta ${ }^{61}$.

W wyniku przeciagającej się III wojny turecko-austriackiej cesarz Rudolf II Habsburg wyprzedawał kolejne dobra w miastach nad Bobrem. W 1601 r. okazję do nabycia nowych źródeł dochodów wykorzystała rada miejska Żagania, wykupując dobra kameralne w mieście za sumę 90000 talarów. W'śród zakupionych dóbr znalazły najstarsze w mieście młyn dolny i górny ${ }^{62}$. Skład rzemiosł zasilanych przez żagański młyn dolny nie uległ dużym zmianom aż do końca XVIII w. Wówczas ujście tamtejszej młynówki było podzielone na pięć rynien roboczych, przy których pracowało pięć kół wodnych, zasilających wspomnianą już kuźnię znajdującą się na lewym brzegu młynówki, a także zakład białoskórniczy, tkalnię oraz młyn dębny ${ }^{63}$.

W czasie, gdy rady w XVI i XVII w. miejskie rozbudowywały swoje młyny wodne, dostawiając kolejne koła wodne i dzierżawiąc je lokalnym rzemieślnikom, na obszarze dorzecza Bobru dokonywał się proces

58 J.G. Bergemann, dz. cyt. s. 45-47.

${ }^{59}$ E. Wernicke, dz. cyt., s. 50; J.G. Bergemann, dz. cyt., s. 45-48.

60 J.G. Bergemann, dz. cyt. s. 45-47.

${ }^{61}$ Tamże, s. 47.

${ }^{62}$ CDS, t. 32, s. 70; A. Leipelt, Geschichte der Stadt und Herzogtums Sagan, Sorau 1853, s. 117.

${ }^{63}$ Archiwum Państwowe w Zielonej Górze (dalej: AP Zielona Góra), Starostwo Powiatowe Żagańsko-Szprotawskie, sygn. 63, Anlage 6a Auszug aus der Situation von den Herzoglichen Werken und Schleusen be idem Sorauer Tore zu Sagan, [bp.]. 
przemiany struktury społeczno-gospodarczej, który zdeterminował dalszy rozwój energetyki wodnej tego obszaru.

Proces bujnego rozwoju miast został zahamowany w XVI w. w wyniku przejęcia zwierzchności nad Ślaskiem przez Habsburgów. Dynastia ta, reprezentująca tendencje centralistyczne, chciała ograniczyć rolę stanów ślasskich, gdzie silną pozycję posiadały miasta ${ }^{64}$. By mocniej zwiazać nową prowincję ze swoim państwem, Habsburgowie poczynili wiele nadań ziemskich dla lokalnej szlachty, na której mieli zamiar oprzeć swe rządy na dotychczas mocno rozdrobnionym i niezależnym Śląsku.

Pomyślny rozwój miast nad Bobrem został przerwany wybuchem wojny trzydziestoletniej (1618-1648), która przyniosła wielkie starty ludzkie i ruinę 36 ślaskich miast, 1095 wsi i 113 zamków. W wyniku walk katolików z protestantami ludność Śląska zmniejszyła się o 30\%. Niektóre obszary wyludniły się całkowicie, a życie miejskie na jakiś czas zamarł $^{65}$. Po pokoju westfalskim z 1648 r. Ślask, a wraz z nim obszar dorzecza Bobru, nadal znajdował się panowaniem katolickich Habsburgów, którzy rozpoczęli proces rekatolicyzacji, co uderzyło przede wszystkim w zdominowane przez protestantów miasta. Skutki wojny wzmocniły zapoczątkowany w drugiej połowie XVI w. proces przechodzenia od gospodarki wczesnokapitalistycznej, gdzie ośrodkami wzrostu były miasta, do typowej dla ówczesnej Europy Środkowo-Wschodniej gospodarki folwarczno-pańszczyźnianej, opartej na wielkiej własności ziemskiej ${ }^{66}$.

$\mathrm{W}$ dziedzinie energetyki wodnej przemiana ta objawiała się w rozwoju młynów wodnych w wielkich posiadłościach ziemskich, gdzie ze względu na charakter gospodarki folwarcznej dominowały młyny zbożowe ${ }^{67}$. Oprócz młynów nastawionych na przetwórstwo płodów rolnych w wielkich własnościach ziemskich rozwijały się także nowe dziedziny produkcji zasilane energia wody - hutnictwo i papiernictwo.

Najobfitsze złoża rudy darniowej występują w środkowym biegu Bobru, gdzie eksploatowane je już od czasów prehistorycznych w prymitywnych dymarkach. Rewolucję w światowym hutnictwie przyniosła umiejętność zastosowania energii wody do napędu młotów i miechów kuźniczych. Znaczniejsze młyny kuźnicze znajdowały się w Lesznie Górnym, Lesznie Dolnym, Dziećmiarowicach oraz w Małomicach. Ta ostatnia kuźnica wzmiankowana była już w 1497 r., a w 1576 r. źródła

${ }^{64}$ G. Was, Dzieje Ślaska od 1526 do 1806 roku, w: Historia Ślaska, red. M. Czapliński, Wrocław 2002, s. 128.

65 Tamże, s. 173.

${ }^{66}$ K. Popiołek, Historia Ślaska. Od pradziejów do 1945 roku, Katowice 1972, s. 100; G. Wąs, dz. cyt., s. 184.

${ }^{67}$ Z. Kwaśny, dz. cyt., s. 488-489. 
mówią też o cechu kowali. W 1602 r. w okolicach Małomic były już cztery kuźnice $^{68}$. W 1572 r. Seifrid von Promnitz zbudował kuźnicę na lewym brzegu rzeki Bóbr w Nowogrodzie Bobrzańskim ${ }^{69}$.

W XV i XVI w. kuźnice funkcjonujące nad środkowym Bobrem były jeszcze w większości własnością rad miejskich, które dzierżawiły je mistrzom kuźniczym. Od XVII w., wraz ze wzrostem pozycji ekonomicznej lokalnej szlachty, grupa ta zdominowała rynek produkcji wyrobów metalowych, dysponując licznymi kuźnicami nad mniejszymi dopływami rzeki w okolicach Szprotawy. Według danych z 1740 r. dobra małomickie wraz z kuźnicą należały już do rodziny von Redern, która miała swe kuźnice również w Iłowej i w Starej Kuźnicy. Hrabiowie von Reuss posiadali kuźnice w Przemkowie. Młyny kuźnicze należące do księcia Lobkowitz funkcjonowały w Świętoszowie nad Kwisą i w Czernej nad rzeką Czerna. Klasztor magdalenek ze Szprotawy miał kuźnicę w Lesznie Dolnym. W Ławszowej nad Kwisa młyn kuźniczy był własnością hrabiów Frankenberg ${ }^{70}$. W późniejszym okresie kuźnica w Ławszowej przynosiła dochody rodzinie Promnitz ${ }^{71}$.

Największym konkurentem dla szlachty w środkowym dorzeczu Bobru była rada miejska Szprotawy, która swe kuźnie posiadała w Lesznie Górnym i Dziećmiarowicach. Miasto zazdrośnie strzegło swoich dochodów, obawiając się konkurencji szlacheckich kuźnic w Iławie. W 1709 r. władze miasta zakazały sprzedaży żelaza, które nie było wytapiane w kuźnicach należących do miasta. Zakaz ten uderzał w posiadaczy kuźnic w okolicy. Hrabia von Redern zagroził nawet utworzeniem przez szlachtę konkurencyjnego dla Szprotawy ośrodka handlu w sąsiedniej Iławie. Groźba była na tyle skuteczna, iż rada miejska wycofała się z zakazu ${ }^{72}$.

Lokalna szlachta przyczyniła się także do rozwoju innej ważnej gałęzi produkcji, która była charakterystyczna dla górnego dorzecza Bobru - papiernictwa. Papiernictwo było dziedziną wytwórczości wymagająca skomplikowanych urządzeń technicznych, wysoko wykwalifikowanych specjalistów i trudnego do zdobycia surowca do produkcji papieru, którym początkowo były stare szmaty. Zbyt wyprodukowanego

${ }_{68}$ M. Boryna, Małomice na rubieży Borów Dolnoślaskich, Żary 2008, s. 34.

69 Tamże, s. 146.

${ }^{70}$ H. Fechner, Geschichte des Schlesischen Berg- und Hüttenwesens in der Zeit Friedrich's des Grossen, Friedrich Wilhelm's II. und Friedrich Wilhelm's III. 1741 bis 1806, t. 2, Berlin 1903, s. 3, 10-11.

71 Tamże, s. 646.

72 J. Kuczer, Szlachta $w$ życiu społeczno-gospodarczym księstwa głogowskiego w epoce habsburskiej 1526-1740, Zielona Góra 2007, s. 210-211. 
papieru również nie był łatwy, gdyż zależał od ogólnego poziomu rozwoju gospodarczego i kulturalnego danego obszaru ${ }^{73}$.

Czynnikami, które sprzyjały rozwojowi młynów papierniczych na tym terenie były przede wszystkim dogodne warunki hydrologiczne. Bóbr i jego dopływy, odznaczające się wysokimi spadkami, dostarczały nie tylko energii napędzającej koła wodne, lecz także czystej wody wykorzystywanej w procesie produkcyjnym ${ }^{74}$. Rozwój młynów papierniczych w dorzeczu Bobru zbiegł się w czasie z rozwojem szkolnictwa, reformacji i kontrreformacji, gdy walka ideowa miedzy poszczególnymi odłamami religijnymi wzmogła ruch wydawniczy, co zaowocowało popytem na papier ${ }^{75}$.

Początkowo młyny papiernicze, ze względu na wysokie koszty budowy, powstawały głównie w większych miastach, gdzie rady miejskie skłonne były wesprzeć finansowo inwestycję w dodatkowe koło wodne, które zasilało stępy papiernicze. Jedną z pierwszych była papiernia w Lwówku Ślaskim, o której pierwsze wzmianki pochodza z 1533 r. Kolejna wzmianka o produkcji papieru w lwóweckim młynie pochodzi z 1695 r., później informacje na temat wyrobu papieru w Lwówku urywają się ${ }^{76}$.

W XVII i XVIII w. walnie do rozwoju młynów papierniczych przyczyniła się rodzina von Schaffgotsch. Dysponowała ona ziemią wraz z prawem do korzystania z rzeki oraz siecią młynów zbożowych, które można było łatwo zaadaptować na młyny papiernicze. Oferowała przybywajacym papiernikom teren i dostęp do rzeki, pozwalając na przebudowę istniejącego młyna lub wzniesienie nowego od podstaw. Po wybudowaniu, względnie zaadaptowaniu takiego młyna, papiernik najczęściej zostawał jego dzierżawcą ${ }^{77}$.

W 1575 r. Hans Schaffgotsch wydzierżawił młyn zbożowy w Orłowicach nad Kwisa papiernikowi Hansowi Helbygowi, który własnym kosztem przebudował go na młyn papierniczy. Młyn ten musiał przynosić Helbygowi znaczne dochody, gdyż niedługo uruchomił on druga papiernię zwaną dolnym młynem papierniczym ${ }^{78}$. W Gryfowie Ślaskim, który był własnością rodziny Schaffgotsch, również funkcjonował młyn

${ }^{73}$ K. Maleczyńska, dz. cyt., s. 18-19.

${ }_{74}$ M. Szymczyk, Dzieje jeleniogórskiego ośrodka przemysłu papierniczego (cz. I do 1945 roku), „Rocznik Jeleniogórski”, t. 33, 2001, s. 95.

${ }^{75}$ K. Maleczyńska, dz. cyt., s. 20.

76 Tamże, s. 149.

77 Tamże, s. 27.

${ }^{78}$ A. Gross, Heimatbuch des Kreises Löwenberg in Schlesien, wyd. 2., Löwenberg 1925 , s. 87. 
papierniczy. Pierwsza wzmianka pisana na jego temat pojawiła się w 1681 r. ${ }^{79}$

W początkach XVII w. młyn papierniczy zaczął funkcjonować również w Janowicach Wielkich nad Bobrem ${ }^{80}$. Dobra janowickie wraz z młynem początkowo należały do rodziny Schaffgotsch. Papiernia funkcjonowała tam z krótką przerwą na czas wojny trzydziestoletniej. W okresie późniejszym Janowice były już własnością rodziny Promnitz. W 1786 r. według urbiarza Janowic Wielkich folwark wraz z młynem papierniczym należał już do rodu zu Stolberg Wenigrode ${ }^{81}$.

Od 1558 r. papier był wyrabiany w Mirsku. W XVII i XVIII w. głównie na dopływach Bobru powstały jeszcze liczne papiernie. W 1672 r. w Piechowicach, na gruntach Schaffgotschów, młyn papierniczy uruchomił Georg Kahl. W Podgórzynie młyn papierniczy uruchomiono w $1681 \mathrm{r}$. W Miszkowicach papiernia funkcjonowała już od 1606 r., a papier wytwarzano tam aż do 1848 r., gdy papiernię przerobiono na młyn zbożowy ${ }^{82}$. W 1676 r. powstał również młyn papierniczy w Jeleniej Górze, który wzmiankowany był jeszcze w $1787^{83} \mathrm{i}$ w $1845 \mathrm{r} .{ }^{84} \mathrm{~W}$ drugiej połowie XVIII w. w Kliczkowie papiernię założył hr. Solms-Klitschdorf. Aż trzy papiernie funkcjonowały w Łęczynie (dziś część Świeradowa). Pierwsza papiernia, zwana dolnym młynem papierniczym, powstała w 1706 r., a spłonęła w 1860 r. Średni młyn papierniczy powstał w 1766 r., a po raz ostatni wzmiankowany był w 1845 r. Powyżej nich znajdowała się papiernia górna uruchomiona w $1748 \mathrm{r}$. W Pobiednej papier w młynie produkowany był w latach 1600-1879. W Miłkowie młyn uruchomiono w 1642 r, a produkcję papieru kontynuowano do 1845 r. Na nizinnym odcinku Bobru, w samej Szprotawie, młyn papierniczy funkcjonował od 1779 r. Był wymieniany jeszcze w 1829 r., ale później kończą się w zmianki źródłowe na jego temat. Z kolei w okolicach Żagania wzmiankowane były trzy młyny papiernicze. W samym Żaganiu (1669, 1850) oraz nad Czerną w Żagańcu (1798) i Wilczycach (1741) ${ }^{85}$.

$\mathrm{W}$ epoce nowożytnej młyny wodne dorzecza Bobru stały się podstawowym źródłem zasilania dla głównych gałęzi produkcji. Jedyną

\footnotetext{
${ }^{79}$ K. Maleczyńska, dz. cyt., s. 148.

80 Tamże, s. 29.

81 Urbarz Janowic Wielkich, w: Urbarze ślaskie z końca XVIII wieku, oprac.
}

K. Orzechowski, Z. Szkurłatowski, Wrocław-Warszawa-Kraków 1961, s. 89, 92-93.

${ }^{82}$ K. Maleczyńska, dz. cyt., s. 149-150.

83 T.Ładogórski, Generalnetabelestatystyczne Ślaska 1787roku, Wrocław 1954, s. 214.

${ }^{84}$ J.G. Knie, Alphabetisch-statistich-topographische Ubersicht der Dorfer, Flecken, Stadte und andern Orte der Konigl. Preuss. Provinz Schlesien, Breslau 1845, s. 839.

${ }^{85}$ K. Maleczyńska, dz. cyt., s. 31, 36, 38, 146-152. 
alternatywą były wiatraki, które zasilały głównie młyny zbożowe. Jak przedstawiała się struktura rzemiosł zasilanych energią wody na poszczególnych odcinkach rzeki? Według danych z 1787 r., na terenie powiatu jeleniogórskiego znajdowało się 125 młynów zbożowych, z czego 120 stanowiły młyny wodne, a 5 wiatraki. Wśród młynów rzemieślniczych było 25 młynów tartacznych, 25 foluszy, 10 młynów dębnych, 5 młynów papierniczych i 1 szlifierski. Na terenie powiatu lwóweckiego było 180 młynów zbożowych (145 wodnych, 35 wiatraków), 22 tartaczne, 8 papierniczych, 5 foluszniczych i 4 dębne. W powiecie szprotawskim były 44 młyny zbożowe (w tym 20 wodnych), 5 tartacznych, 2 papiernicze i 1 dębny. W powiecie żagańskim funkcjonowało 96 młynów zbożowych (w tym 68 wodnych), 21 tartacznych i po 2 młyny papiernicze, folusznicze i dębne ${ }^{86}$. Nie jest to obraz pełny, gdyż generalne tabele statystyczne Ślaska z 1878 r. nie ujęły np. młynów kuźniczych.

\section{Epoka przemysłowa}

Wiek XIX był okresem wielkich przemian społeczno-gospodarczych. Wojny napoleońskie przyniosły zniesienie resztek ustroju feudalnego w wielu krajach Europy. Obawa przed rewolucją skłoniła panujące na Ślasku władze pruskie do przeprowadzenia licznych reform, które przyczyniły się do wprowadzenia energetyki wodnej w dorzeczu Bobru na nowe tory. W $1807 \mathrm{r}$. zniesiono poddaństwo chłopów, którzy otrzymali prawo opuszczania wsi i wolność wyboru zawodu. W 1810 r. przeprowadzono sekularyzację dóbr kościelnych, w tym licznych folwarków i młynów należących do klasztorów i biskupstw ${ }^{87}$.

Efektem reform z początku XIX w. był demontaż resztek ustroju feudalnego i otwarcie drogi nowemu systemowi gospodarczemu - liberalnemu kapitalizmowi. Najmocniej reformy uderzyły w pozycję rzemiosła miejskiego. Reforma miejska z 1808 r. zniosła przywileje cechowe, przez co młynarze utracili swoje monopole i przymusy mlewa. Państwo otworzyło zawody rzemieślnicze dla osób spoza korporacji, a także popierało rozwój szkolnictwa zawodowego i zachęcało do wyjazdów do Anglii celem poznania techniki przemysłowej ${ }^{88}$. Zniesienie pańszczyzny

86 T. Ładogórski, dz. cyt., s. 311.

${ }^{87}$ K. Popiołek, dz. cyt., s. 154-155.

${ }_{88}$ M. Czapliński, Dzieje Ślaska od 1806 do 1945 roku, w: Historia Ślaska..., s. 254-256, 262. 
uderzyło również $\mathrm{w}$ rentowność wielkich posiadłości ziemskich, jednak lokalnej szlachcie udało się w XIX w. utrzymać swoją pozycję ekonomiczna ${ }^{89}$.

Bogata szlachta ślaska, po olbrzymich nadaniach w epoce habsburskiej i po sekularyzacji klasztorów w XIX w. postanowiła wykorzystać swój kapitał i dostęp do taniej, bezrolnej siły roboczej. W połowie XIX w. na Śląsku powstawać zaczęły wielkie koncerny przemysłowe w oparciu o majątki ziemskie. Największe pod względem kapitałowym przedsiębiorstwo stworzyła rodzina Schaffgotsch, która posiadała liczne folwarki i zakłady przemysłowe w dorzeczu Bobru, Kotlinie Kłodzkiej, na Opolszczyźnie i na Górnym Ślasku ${ }^{90}$.

Umocnienie pozycji arystokracji w początkach XIX w. uczyniło z niej inicjatora ery przemysłowej w dorzeczu Bobru. Jako pierwsze do produkcji fabrycznej przeszły zdominowane przez arystokrację młyny kuźnicze i papiernicze. Pierwsze huty na tym obszarze powstały na bazie młynów kuźniczych w okolicach Szprotawy i Bolesławca. W latach 1757-1758 należący do rodziny Promnitz młyn kuźniczy w Ławszowej przebudował Abraham D. Werner, instalując nowoczesne piece. Dzięki kolejnym udoskonaleniom kuźnica w Ławszowej w 1847 r. stała się nowoczesną hutą ${ }^{91}$.

Podobna ewolucję przeszedł młyn kuźniczy w Małomicach nad Bobrem. Pod koniec XVIII w. dobra małomickie od hrabiów von Redern przejęła rodzina von Dohna. W latach 1798-1800 rodzina rozbudowała stary młyn kuźniczy, dając początek hucie Maria ${ }^{92}$. W sasiedniej Szprotawie, na bazie młyna kuźniczego, rozwinęła się huta Wilhelma. Obie huty przyczyniły się do zamykania małych młynów kuźniczych w okolicy, np. rada miejska Szprotawy musiała sprzedać swoje kuźnice w Lesznie Górnym i Dziećmiarowicach, gdyż te nie wytrzymywały konkurencji z dużymi hutami w Małomicach i Szprotawie ${ }^{93}$. Młyn kuźniczy w Lesznie Górnym kupiła od miasta firma, która przekształciła go w młyn papierniczy, pracujący na potrzeby fabryki papieru ${ }^{94}$.

W XIX w. ewolucję w kierunku produkcji fabrycznej przechodziły również młyny papiernicze. Stare szmaty, które dotychczas

${ }^{89}$ K. Popiołek, dz. cyt., s. 154-157.

90 M. Czapliński, dz. cyt. s. 265, 302.

91 J. Sawicka, Z. Abramowicz, Osiecznica. Dzieje zielonej gminy, Suwałki 2010, s. $129-139$.

92 R. Glied, Mallmitz, Kreis Sprottau in Niederschlesien, Egelsbach 1984, s. 11-14.

${ }_{93}$ F. Matuszkiewicz, Historia Szprotawy, tłum. J. Kuczer, Szprotawa 2010, s. $236-237$.

${ }_{94}$ Tamże, s. 237. 
wykorzystywano do produkcji papieru, zastapił nowy surowiec drewno, gdy w 1843 r. w sassiedniej Saksonii Friedrich Gottlob Keller opracował metodę mechanicznego rozdrabniania drewna ${ }^{95}$.

Energii nadal dostarczały tam koła wodne. Jednak nie napędzały już stępów, lecz nowoczesne maszyny papiernicze o dużych mocach przerobowych. Ze względu na fakt, iż papiernictwo nie wymagało tak wielkich nakładów finansowych jak hutnictwo, w dziedzinie tej z lokalna szlachta coraz śmielej konkurowali lokalni przedsiębiorcy. Produkcję papieru metoda fabryczna rozpoczęto nad Bobrem najwcześniej w Dąbrowicy koło Jeleniej Góry. Fabrykę papieru, na bazie przebudowanego młyna zbożowego, uruchomili tu w 1837 r. J.E. Keßling i F.W. Schlöffel ${ }^{96}$.

Największe rozmiary przemysł papierniczy osiagnął w okręgu jeleniogórskim. Według sprawozdań jeleniogórskiej kamery handlowej pod koniec XIX w. funkcjonowało tam 21 fabryk ścieru drzewnego, dostarczajacych surowca dla 12 fabryk papieru, 2 fabryk celulozy i 1 fabryki masy papierowej. W przemyśle tym zatrudnionych było wówczas 1800 ludzi, a prawie wszystkie zakłady napędzane były energia wody ${ }^{97}$. W samej Jeleniej Górze powstały trzy nowe fabryki papieru. W 1850 r. Julius Erfurt uruchomił produkcję papieru w młynie zlokalizowanym na młynówce Bobru. W 1853 r. założył druga papiernię przy tej samej młynówce. W 1851 r. jego brat Friedrich kupił młyn zbożowy położony nieco w górę rzeki Bóbr w Strupicach. Na jego bazie uruchomił papiernię, która weszła w skład spółki Gebrüder Erfurt ${ }^{98}$.

W większości fabryki papieru napędzane przez koła wodne zlokalizowane były na mniejszych dopływach górnego Bobru. W Ławszowej stary młyn papierniczy w 1853 r. kupił pochodzacy z Hesji Filip Huttenmuller i wykorzystał go do zasilania fabryki papieru. Po śmierci Huttenmullera jego majątek nabył hrabia zu Solms, który wydzierżawił papiernię synowi Huttenmullera - także Filipowi ${ }^{99}$. Papiernia Huttenmullera musiała dobrze prosperować, gdyż dysponował on kapitałem, by zainwestować w papiernię w sasiedniej Osiecznicy, gdzie młyn papierniczy funkcjonował już od 1585 r. W 1880 r. został przekształcony $\mathrm{w}$ fabrykę papieru należącą do firmy Huttenmuller \& Comp. Jednak pod koniec XIX w. firma popadła w kłopoty finansowe, gdyż

${ }_{95}$ M. Szymczyk, dz. cyt., s. 96.

96 Tamże, s. 98-99.

${ }_{97}$ P. Werth, Die Handelskammer zu Hirschberg in Schlesien 1850-1900. Ein geschichtlicher Rückblick, Hirschberg 1900, s. 29-30.

${ }_{98}$ M. Szymczyk, dz. cyt., s. 103-104.

99 J. Sawicka, Z. Abramowicz, dz. cyt., s. 135. 
osiecznicką papiernię przejęła firma Reimann \& Thonke, która przywróciła starej papierni świetnośćc ${ }^{100}$.

W XIX w. zmechanizowano także liczne młyny papiernicze uruchamiane w XVII w. na dopływach Bobru. W Łęczynie nad Kwisa w 1860 r. papierniczy młyn dostosowano do fabrycznej produkcji tektury ${ }^{101}$. W połowie XIX w. papiernię zasilał również młyn papierniczy pracujaccy od 1610 r. w Janowicach Wielkich ${ }^{102}$. W latach 1844-1845 w Miłkowie nad Łomnica Ewald Gebauer zmodernizował młyn papierniczy, czyniąc z niego nowoczesną fabryke papieru, która po kolejnych rozbudowach produkowała pod koniec XIX w. 4000 ton papieru ${ }^{103}$. Kolejne fabryki papieru na bazie młynów uruchomiono w Łomnicy $(1849)^{104}$ i Piechowicach $(1853)^{105}$.

Rozmiary fabryk i wielkość produkcji powodowały, że koła wodne nie były w stanie w pełni zaspokoić zapotrzebowania na energię. Poza tym rozwój kolei umożliwił dostarczanie węgla do napędu maszyn parowych oraz wywozu gotowych produktów, co umożliwiało dalsze zwiększanie produkcji. W połowie XIX w. w wielu fabrykach oprócz kół wodnych energii dostarczały nowe źródła wytwórcze, takie jak maszyna parowa, a później również silniki spalinowe, które dysponowały większymi mocami i powoli wypierały mało wydajne wówczas koła wodne.

Instalowanie maszyn parowych zaowocowało powstaniem tak zwanych młynów wodno-parowych. Tak było w wielkiej przędzalni lnu w Mysłakowicach pod Jelenią Góra, która zasilana była przez dwa koła wodne o łącznej mocy $130 \mathrm{KM}$ i sześć maszyn parowych o łącznej mocy $350 \mathrm{KM}^{106}$. Podobna sytuacja miała miejsce w licznych papierniach. Na przykład w Dąbrowicy w 1852 r. młyn przyfabryczny wsparły dodatkowo maszyny parowe ${ }^{107}$.

Proces ekspansji maszyn parowych w zakładach zlokalizowanych nad Bobrem został zahamowany dzięki skonstruowaniu pierwszych turbin wodnych, które nad Bobrem pojawiły się w drugiej połowie XIX w. W Bolesławcu młyn górny funkcjonował jako młyn miejski aż

\footnotetext{
100 Tamże, s. 133-134.

101 K. Maleczyńska, dz. cyt., s. 149.

102 Tamże, s. 148.

${ }_{103}$ M. Szymczyk, dz. cyt., s. 100.

104 Tamże, s. 103.

105 Tamże, s. 107.

106 J.T. Eisenmänge, Der Kreis Hirschberg. Seine Natur, Industrie, Bewohner, Verwaltung und Ortschaften. Ein Handbuch für Freunde des Riesengebirges und der Heimathskund, Hirschberg 1879, s. 87.

${ }^{107}$ M. Szymczyk, dz. cyt., s. 98-99.
} 
do roku 1813. Po zniesieniu przywilejów cechowych, cały młyn górny na własność wykupił od miasta dotychczasowy dzierżawca, Friedrich Gläser ${ }^{108}$. W 1871 r. młyn górny został strawiony przez pożar. Spalony obiekt wraz z uprawnieniami do korzystania z wód rzeki Bóbr zakupił brytyjski przemysłowiec Samson Woller. Na działce należącej do młyna zbudował nowoczesny zakład wełny czesankowej (od $1888 \mathrm{r}$. zakład nazywał się Concordia Spinnerei und Weberei AG). W odbudowanym młynie górnym zainstalował turbinę o mocy $80 \mathrm{KM}$, która zasilała przędzalnię ${ }^{109}$.

W drugiej połowie XIX w. turbiny wodne pojawiły się również w żagańskim młynie dolnym. Z zachowanych dokumentów wynika, że na początku lat 80. XIX w. energię wody wykorzystywała firma Christof-Sagan, która w 1882 r. zainstalowała w swoim młynie turbinę wodna o mocy $75 \mathrm{KM}^{110}$. W 1891 i 1892 r. dwie turbiny o mocy 122 i $130 \mathrm{KM}$ dostawiła austriacka firma włókiennicza Moses Löw Beer, która przy młynie dolnym otworzyła swój zakład ${ }^{111}$. W tym samym okresie piętrzenie wody na lewym brzegu młynówki wykorzystywał także zakład tkacki firmy należący do żarskiego kupca Carla Zehe. Zakład ten również został wyposażony $\mathrm{w}$ turbinę, osiagająca moc 178,6 KM ${ }^{112}$.

Proces wymiany kół wodnych na turbiny przybrał na sile wraz z postępująca koncentracją i modernizacją śląskiego przemysłu, które przyspieszyły po zjednoczeniu Niemiec. Po $1871 \mathrm{r}$. niemiecka gospodarkę zasilały francuskie reparacje w wysokości 5 mld franków w złocie, co przyczyniło się do rozwoju rynku finansowego, który miał wesprzeć modernizację przemysłu ${ }^{113}$. Na Ślasku zasobność trzech największych instytucji finansowych zwiększyła się z 18 mln marek w 1870 r. do 120 mln marek w 1872 r. Do największych banków należały Wrocławski Bank Dyskontowy, Wrocławski Bank Wekslowy i Ślaski Akcyjny Bank Ziemski ${ }^{114}$.

Banki wzięły udział w tworzeniu spółek akcyjnych, konsolidujących lokalne zakłady przemysłowe ${ }^{115}$. Proces ten na obszarze dorzecza

108 E. Wernicke, dz. cyt., s. 50; J.G. Bergemann, dz. cyt. s. 45-48.

109 K. Popiński, Życie gospodarcze w latach 1806-1945, w: Bolesławiec. Zarys monografii miasta, red. T. Bugaj, K. Matwijowska, Wrocław-Bolesławiec 2001, s. 145-146.

${ }_{110}$ AP Zielona Góra, Starostwo Powiatowe Żagańsko-Szprotawskie, sygn. 63, Anlage B Ubersicht über die historische Entwicklung der Triebwerkanlagen am Bober in Sagan und über die sonstigen Verhältnisse am Bober auf dieser Strecke [bp.].

111 Tamże.

112 Tamże.

113 Cz. Łuczak, Dzieje gospodarcze Niemiec 1871-1945, Poznań 1984, s. 24.

114 T. Afeltowicz, Studia nad historia banków ślaskich (do roku 1918), WrocławWarszawa-Kraków 1963, s. 166.

115 Tamże, s. 153. 
Bobru został zapoczątkowany w 1871 r., gdy ród von Dohna sprzedał swoją hutę w Małomicach firmie Schuster-Bank Berlin, która na bazie majątku huty założyła spółkę akcyjna. W 1898 r. spółka przekształciła się w firmę Internationalen Metallwerke, która rozpoczęła konsolidację lokalnego przemysłu hutniczego, nabywając hutę Maria w Chocianowie i hutę Wilhelma w Szprotawie ${ }^{116}$. Podobne procesy koncentracji zachodziły również $\mathrm{w}$ innych gałęziach produkcji. Na bazie powstałej z bolesławieckiego młyna górnego przędzalni powstała w $1888 \mathrm{r}$. spółka Concordia Spinnerei und Weberei AG, w skład której weszły przedsiębiorstwa produkujące tekstylia z Bolesławca, Leśnej i Kościelników koło Lubania ${ }^{117}$. W środkowym dorzeczu Bobru lokalne fabryki papieru i kartonu skonsolidowane zostały w spółce Schlesische Pappenfabrik AG powołanej do życia w 1900 r. Papiernie okręgu jeleniogórskiego zostały połączone w 1892 r. w spółce Schlesische Cellulose und Papierfabriken $\mathrm{GmbH}$, która początkowo funkcjonowała jako spółka z ograniczoną odpowiedzialnościa. W jej skład weszły papiernie w Łomnicy, Mroczkowicach, Janowicach Wielkich i w Jeleniej Górze-Kunowicach. Powstały w wyniku konsolidacji koncern papierniczy w 1895 r. przekształcił się w spółkę akcyjną z kapitałem 1050000 marek, a jej głównym udziałowcem były wrocławskie banki Breslauer Disconto Bank i Bankhaus Marcus Nelken \& Sohn oraz mniejsi udziałowcy, jak jeleniogórskie towarzystwo handlowe Abrahama Schlesingera i dwaj rentierzy Hugo Hejman z Wrocławia i Ernst Rumpel z Jeleniej Góry ${ }^{118}$.

\section{Rozwój elektrowni przyfabrycznych}

Zwiększająca się produkcja fabryk zlokalizowanych nad Bobrem trafiała do coraz dalszych odbiorów za sprawą rozwoju kolei i pozyskiwania nowych rynków zbytu w tworzonym przez zjednoczone Niemcy imperium kolonialnym. By nadążyć z realizacją zamówień, fabryki potrzebowały coraz więcej energii, której nie były już w stanie zapewnić młyny z turbinami wodnymi. Dotychczas do łatania niedoborów energii oprócz kół i turbin wodnych lokalni fabrykanci często decydowali się na maszyny parowe i silniki dieslowskie. Jednak w dorzeczu Bobru większość zużywanej energii wytwarzana była w pierwszej

116 R. Glied, dz. cyt., s. 15-18.

117 K. Popiński, dz. cyt., s. 146.

118 M. Szymczyk, dz. cyt., s. 101-102. 
połowie XX w. w siłowniach wodnych. Złożyły się na to dwa czynniki. Po pierwsze, w 1900 r. rozpoczęto zakrojony na szeroka skalę program regulacji dorzecza Bobru autorstwa profesora Ottona Intzego, który postulował, by w dorzeczu rzeki wybudować 19 zbiorników wodnych, a także uregulować koryta rzeczne ${ }^{119}$. Projekt Intzego przewidywał wykorzystanie spiętrzonej wody do zaopatrywania w wodę miast oraz do celów przemysłowych i energetycznych ${ }^{120}$. Powstała infrastruktura wyrównała przepływy w rzece, czyniąc ją niezwykle atrakcyjna pod względem inwestycji w energetykę wodna. Drugim czynnikiem był fakt, że większość fabryk zlokalizowanych w dorzeczu Bobru powstała na bazie młynów wodnych. By uruchomić elektrownię wodna wystarczyło w zasadzie zaadaptować młyn poprzez wymianę koła wodnego na turbinę i kupno generatora prądu. Reszta infrastruktury w postaci budynku, jazu piętrzącego wodę i młynówki już istniała.

Uruchamiane w początkach XX w. elektrownie wodne nad Bobrem odzwierciedlały strukturę lokalnego przemysłu, która była dziedzictwem wielowiekowego rozwoju. Według danych z $1896 \mathrm{r}$. w dorzeczu tej rzeki funkcjonowały 124 zakłady korzystające $\mathrm{z}$ energii wody. Wśród nich było 48 młynów zbożowych, 14 przędzalni, foluszy i zakładów sukienniczych, 23 tartaki, 29 papierni, ścieralni drewna i fabryk tektury, 4 huty, 5 szlifierni szkła i 1 słodownia ${ }^{121}$. Nie ma tu miejsca, by omawiać wszystkie przypadki modernizacji młynów wodnych w elektrownie, dlatego proces ten zostanie omówiony na kilku przykładach, a szczegółowy wykaz zawiera Załącznik 1.

Pierwsze elektrownie powstały na bazie młynów przy hutach i fabrykach papieru. W środkowym biegu rzeki Bóbr pierwsze elektrownie wodne uruchamiano na bazie dawnych młynów kuźniczych, które przez XIX w. zasilały lokalne huty. Hutę w Małomicach, przejął w 1910 r. przemysłowiec Georg Sindermann, który w młynie wymienił koła wodne na dwie turbiny o mocy $0,18 \mathrm{MW}$ każda, dostarczające energii

119 O. Intze, Bericht uber die Wasserverhaltnisse der Gebirgsflusse Schlesiens im Bober- und Queissgebiete sowie im Gebiete der Glatzer Neisse und deren Verbesserung zur Ausnutzung der Wasserkrafte sowie zur Verminderung der Hochwasserschaden durch Anlage von Sommelbecken, Berlin 1899, s. 1-6, 24-25.

120 Tamże, s. 16.

${ }^{121}$ E. Althans, Mittel und Wege um von den Gebrigsflüssen Schlesiens zunächst den Queis und Bober nicht nur unschädlich, sondern für Land und Leute, besonders auch für die Schiffhart in Schlesien volkswirtschaftlich nutzbar zu machen. Vortrag am 6. Juli 1896 beim 30. Schles. Gewerbetag in Löwenberg, Breslau 1896, s. $5-6$. 
mechanicznej dla dwóch generatorów prądu stałego ${ }^{122}$. Kolejna elektrownia przy hucie huta powstała w 1910 r. w Szprotawie. Poczatkowo dysponowała dwiema turbinami. Po regulacji Bobru w okolicach Szprotawy huta wystapiła do władz lokalnych o pozwolenie na trzecią turbinę ${ }^{123}$. Ostatecznie w 1933 r. siłownia przy szprotawskiej hucie dysponowała moca $0,735 \mathrm{MW}^{124}$.

Regulacja Bobru była także impulsem do inwestycji w żagańskie młyny wodne. W 1904 r. firma przędzalnicza Moses Löw Beer, która wykorzystywała młyn dolny, zakupiła dwie podwójne turbiny o łącznej mocy 0,8 MW' $\mathrm{MW}^{125}$. W $1922 \mathrm{r}$. firma zamówiła dodatkową turbinę o mocy 0,735 MW, by zaspokoić zapotrzebowanie na energię w rozrastającej się przy młynówce fabryce ${ }^{126}$. Rok później władze Księstwa Żagańskiego zdecydowały się przebudować młyn górny, gdzie w miejsce kół wodnych wstawiono dwie turbiny o łącznej mocy 0,4 $\mathrm{MW}^{127}$. W kolejnych latach elektrownia była rozbudowywana.

Wiele elektrowni powstało również na bazie młynów papierniczych. Znaczniejsza elektrownia przy fabryce papieru powstała w Starej Olesznie koło Bolesławca. W 1910 r. lokalny producent papieru Artur Elsner przekształcił młyn papierniczy w elektrownię o mocy 1,2 $\mathrm{MW}^{128}$.

Wspomniane dotychczas elektrownie zlokalizowane były w dolnym i środkowym dorzeczu Bobru, gdzie wahania poziomu wody w latach mokrych i suchych były mniej odczuwalne, a podczas wezbrań rzeka ze względu na niższe spadki nie powodowała tak wielkich zniszczeń, jak w górnym odcinku. Wraz z postępującą regulacja, wyrównaniem przepływów w rzekach i ograniczeniem ryzyka powodzi, również przedsiębiorcy posiadający zakłady w górnym biegu rzeki decydowali się na inwestycje mające na celu modernizację bazy energetycznej ich przedsiębiorstw. Elektrownie takie powstały m.in. w okolicach

${ }^{122}$ R. Glied, dz. cyt., s. 109.

${ }^{123}$ Archiwum Państwowe we Wrocławiu (dalej: AP Wrocław), Naczelne Prezydium Prowincji Ślaskiej, Wydział Ogólny, sygn. 459, Der Landeshauptmann an den herr Landratt. Betrifft Konzessionsunterlagen für den Umbau der Wasserkraftanlage der Wilhelmhütte in Eulau, k. 542-543.

124 AP Zielona Góra, Starostwo Powiatowe w Szprotawie, sygn. 83, Erläuterungsbericht, k. 837.

${ }_{125}$ AP Zielona Góra, Starostwo Powiatowe Żagańsko-Szprotawskie, sygn. 63, Anlage B... [bp.].

126 Tamże.

127 AP Zielona Góra, Archiwum Książąt Żagańskich, sygn. 796, Bericht über den Ausbau des Herzoglichen Elektrizitätswerke Sagan, k. 33.

${ }^{128}$ AP Wrocław, Wydział Samorządowy Prowincji Śląskiej, sygn. 3330, Betrifft Wasserkraft Altöls, k. 156. 
Siedlęcina, gdzie w 1923 r. przy papierni uruchomiono elektrownię o mocy $0,127 \mathrm{MW}^{129}$. Nieco w dół rzeki elektrownia dla potrzeb fabryki wyrobów drzewnych została uruchomiona w młynie tartacznym ${ }^{130}$.

\section{Epoka powszechnej elektryfikacji}

W elektrowniach przyfabrycznych instalowano turbiny o wyższych mocach niż wskazywały na to realne potrzeby. Ustanawiano w ten sposób rezerwę mocy dyspozycyjnej na wypadek rozbudowy fabryki. Dzięki rozwojowi lokalnych systemów energetycznych nadwyżki energii mogły być odsprzedawane za pomoca linii przesyłowych do dalszych odbiorców. W sytuacji, gdy prawie każdy zakład przemysłowy miał własne źródło energii w postaci elektrowni wodnej lub cieplnej, najpoważniejszym partnerem handlowym były samorządy.

Współpraca miedzy samorządami a prywatnymi przedsiębiorcami początkowo odbywała się na mała, lokalną skalę. W obliczu braku regulacji w sektorze energetycznym, do wytyczania tras przewodów wysokiego napięcia używano prawa drogowego, gdyż wzdłuż dróg publicznych lokowano sieci przesyłowe ${ }^{131}$. Samorządy ułatwiały procedury administracyjne, oczekując $\mathrm{w}$ zamian niskich taryf energetycznych na oświetlenie miasta.

Po raz pierwszy do takiej współpracy doszło już pod koniec XIX w. W 1894 r. Hermann Saalmann uruchomił elektrownię na bazie młyna zbożowego w Nowogrodzie Bobrzańskim ${ }^{132}$. Elektrownia Saalmanna oprócz dwóch turbin wodnych o mocy 0,185 MW, wspomaganych przez maszynę parowa, dodatkowo wykorzystała znajdujące się jeszcze w młynie stare koło wodne. Urządzenia te sprzegnięte zostały z generatorem prądu trójfazowego, wytwarzającym energię elektryczna, przesyłaną do oddalonej o $25 \mathrm{~km}$ Zielonej Góry ${ }^{133}$. Linia powstała na mocy umowy z 25 stycznia 1895 r. zawartej z zarządem miejskim w Zielonej Górze. Zgodnie z tą umową w 1925 r. elektrownia przeszła na własność

${ }^{129}$ Archiwum Zakładowe (dalej: AZ) Tauron, Biuro Studiów i Dokumentacji Zabytków Techniki, brak sygn., Elektrownia wodna Bobrowice III [bp.].

${ }_{130}$ Tamże, Elektrownia wodna Bobrowice II [bp.].

131 A. Schönberg, E. Glunk, Landes-Elektrizitätswerke, München-Berlin-Oldenbourg, 1926, s. 1.

132 Z. Bujkiewicz, Krajobraz materialny i społeczny Zielonej Góry od końca XVIII do połowy XX wieku. Przestrzeń - ludność - gospodarka, Zielona Góra 2003, s. 222-223.

${ }^{133}$ H. Saalmann, Elektricitätswerke Eichdorf-Grünberg, w: Schlesien. Kultur und Arbeit einer deutschen Grenzmark, red. B. Salomon, E. Stein, Berlin 1926, s. 245. 
miasta, które wniosło je jako aport do spółki elektryfikacyjnej założonej wspólnie z lokalnymi fabrykantami. Spółka Elektrowirtschaft Grünberg GmbH koordynowała gospodarkę energetyczną na terenie miasta i powiatu zielonogórskiego, dystrybuując nadwyżki energii z elektrowni przyfabrycznych ${ }^{134}$.

W drugiej dekadzie XX w. współpracę z samorządami zdominowały wielkie firmy energetyczne, które tworzyły z zarządami powiatów i prowincji spółki elektryfikacyjne. Pomysłodawca takiej formy elektryfikacji był Emil Rathenau, który w młodości spędził sporo czasu na Bobrem, odbywając czteroletnią praktykę w szprotawskiej hucie. W $1887 \mathrm{r}$. Rathenau powołał do życia spółkę Allgemeine Elektricitäts-Gesellschaft $(\mathrm{AEG})^{135}$. W samorządach upatrywał partnera, z którym współpraca mogła przynieść wiele korzyści. Do 1911 r. AEG było udziałowcem 114 publicznych spółek elektryfikacyjnych, co stanowiło 31\% udziału w niemieckim rynku energii ${ }^{136}$. Największą tego typu spółką na terenie Niemiec była Rheinisch-Westfälisches Elektrizitätswerk (RWE), która powstała w 1898 r. we współpracy koncernu AEG i miasta Essen. Spółka ta krótkim czasie podpisała umowy z wielkimi fabrykami dorzecza Ruhry, takimi jak zakłady Friedricha Kruppa, odkupując od nich nadwyżki energii. W 1902 r. August Thyssen przeją większościowy pakiet akcji w spółce RWE, i kontynuował konsolidację dostawców i odbiorców energii elektrycznej w dorzeczu Ruhry ${ }^{137}$.

Dorzecze Bobru zdominowała spółka inwestycyjna AEG - Elektrowerke AG, która wspólnie z Zarządem Prowincji Ślaskiej powołała do życia w 1902 r. Prowincjonalne Zakłady Elektryfikacyjne z siedzibą w Jeleniej Górze (Provinzial-Elektrizitätswerk Hirschberg, PEW). Zarząd Prowincji Śląskiej postanowił wykorzystać infrastrukturę hydrotechniczna powstała w wyniku regulacji dorzecza Bobru. Prowincja śląska, jako największy udziałowiec PEW, wniosła do niej aportem elektrownie wybudowane przy zaporach ze środków budżetu prowincjonalnego ${ }^{138}$. Najszybciej powstały elektrownie przy zaporach w Leśnej i Pilchowicach (Załącznik 2).

Pierwsze elektrownie przy zbiornikach, podobnie jak elektrownie lokalnych przedsiębiorców, również posiadały wyższe moce niż wskazywałyby na to lokalne potrzeby. Po powstaniu gęstej sieci elektrowni

${ }^{134}$ Elektrowirtschaft, w: Brandenburg. Kultur und Arbeit..., s. 38.

135 G. Siegel, Die öffentliche Elektrizitätsversorgung Deutschlands, „Die Naturwissenschaften" 42, 1917, s. 641.

136 T.P. Hughes, dz. cyt., s. 179.

137 Tamże, s. 410-411.

${ }^{138}$ C. Bachmann, Die Elektricitätswirtschaft, w: Schlesien..., s. 85-86. 
wodnych przy fabrykach i zainwestowaniu wielkich środków w nowe elektrownie przy zaporach, energetyka wodna w dorzeczu Bobru oczekiwała na czynnik, który wyzwoliłby drzemiący w niej potencjał niewykorzystanej mocy. Czynnikiem tym była I wojna światowa, podczas której sieć przesyłowa uległa szybkiej rozbudowie, celem zasilania ośrodków przemysłu zbrojeniowego. Również okres powojenny sprzyjał rozwojowi energetyki wodnej na Bobrze. Wzrost cen węgla kamiennego spowodowany okupacja zagłębia Saary i utratą Górnego Śląska spowodował w Niemczech problemy z podażą tego surowca. Dlatego też dyrektor PEW, Curt Bachmann, na spotkaniach rady budowy zapór wskazywał na wzrastająca opłacalność ekonomiczną elektrowni wodnych. Powoływał się dane, według których jeszcze w 1914 r. tona węgla kosztowała 13,80 marek, pod koniec 1919 r. było to już 96,50 marek, by pod koniec 1921 r. osiagnąć 462,70 marek za tonę ${ }^{139}$.

Dzięki temu C. Bachmann miał argument w staraniach o pozyskanie środków na rozwój bazy energetycznej na rzekach sudeckich. W latach 20. XX w. prowincjonalna kasa pomocowa udzieliła PEW wsparcia, dzięki czemu ta mogła rozbudowywać swoją bazę energetyczną ${ }^{140}$. W latach 1924-1925 rozpoczęto budowę elektrowni przy powstajacej zaporze w Siedlęcinie. Zaznaczono wówczas jednocześnie, że z powodu niedoborów węgla kamiennego planowane są kolejne elektrownie wodne na Bobrze poniżej Siedlęcina ${ }^{141}$. Bachmann planował, że głównymi odbiorcami energii będą miasto Jelenia Góra, kolej doliny Bobru i wielki przemysł okręgu sudeckiego ${ }^{142}$.

W 1931 r. zakończył się okres, na jaki powołano spółkę PEW. Zarówno władze prowincji, jak i firma Elektrowerke zadowolone z dotychczasowej współpracy powołały do życia na bazie dotychczasowej nową spółkę - Dolnoślaskie Zakłady Elektryfikacyjne (Niederschlesischen Elektrizitäts AG, NEAG) ${ }^{143}$. Symboliczną ilość akcji w nowej spółce kupiło niemieckie zjednoczenie przemysłowe:

139 AP Jelenia Góra, Akta Miasta Jelenia Góra (dalej: AMJG), sygn. 9115; Niederschrift über zweite Sitzung des Beirats der Talsperren in Hirschberg am 28. Januar 1922, k. 2-3; tamże, Anlage 1. Selbskosten der Stromlieferung des P.E.W, k. 3 .

140 AP Wrocław, Wydział Samorządowy Prowincji Śląskiej, sygn. 164, Direktor der Provinzial-Hilfskasse für die Provinz Schlesien zu Provinzial Verband Schlesien, passim.

${ }^{141}$ AP Jelenia Góra, AMJG, sygn. 9116, Beschreibung der von dem Provinzialverband von Schlesien projektirten Stauanlage im Bober bei Boberröhrsdorf, k. 8-10.

${ }_{142}$ AP Jelenia Góra, AMJG, sygn. 9116, Betrifft Boberwasserkraft, k. 94.

${ }^{143}$ Landes Archiv Berlin, A rep. 250-03-07, sygn. 240, Konsortialvertrag zwischen Provinz Niederschlesien und Elektrowerke AG [bp.]. 
Vereinigte Industrieunternehmungen AG (VIAG) oraz spółka zajmująca się eksploatacją węgla brunatnego: Mitteldeutche Montanwerke i grupa kapitałowa Reichskredit Gesellschaft ${ }^{144}$.

Objecie symbolicznych pakietów akcji dawało tym podmiotom prawo udziału w walnym zgromadzeniu akcjonariuszy. Instytucjom tym zależało na możliwości dalszej ekspansji kapitałowej na rynku śląskim. Zwłaszcza Elektrowerke i Mitteldeutsche Montanwerke szukały rynku zbytu dla energii wytwarzanej w wielkich elektrowniach opalanych węglem brunatnym w zagłębiu łużyckim. Elektrownie te były dziedzictwem I wojny światowej, podczas której w Niemczech rozwinęły się sieci energetyczne, transportujące energię do ośrodków, gdzie zlokalizowany był przemysł zbrojeniowy. Węgla brunatnego ze względu na jego niską kaloryczność nie opłacało się transportować koleją do odległych ośrodków przemysłowych i miast. Najkorzystniejszym rozwiązaniem była budowa elektrowni przy kopalniach odkrywkowych i rozbudowa sieci przesyłowych wysokich napięć, dlatego również po wojnie $\mathrm{w}$ energetyce niemieckiej trwał silny trend w kierunku rozwoju sieci energetycznych, co pozwoliłoby lepiej spożytkować dostępne moce $\mathrm{w}$ elektrowniach ${ }^{145}$.

Szukając rynków zbytu, Elektrowerke zawiązywała z samorządami korzystne dla nich umowy na tworzenie spółek elektryfikacyjnych. Prowincja śląska, ze względu na dobrze rozwinięty, energochłonny przemysł, była do tego najlepszym partnerem. W umowie powołującej do życia NEAG zaznaczono, iż Elektrowerke AG pozostanie jedynym na obszarze prowincji dostawca energii dla kolei niemieckich oraz przedsiębiorstw wchodzących w skład VIAG. Przede wszystkim miała prawo dostarczać im energii z wielkich elektrowni opalanych węglem brunatnym zlokalizowanych na Łużycach ${ }^{146}$. W umowie tej wyrażono również obopólną chęć współpracy przy elektryfikacji innych części prowincji a także dostarczania energii przez Elektrowerke dla miast i związów komunalnych, czemu miały służyć kolejne spółki powoływane we współpracy z prowincją ślaską ${ }^{147}$.

Umowa powołująca NEAG przewidywała, oprócz eksploatacji dotychczasowych elektrowni, dalszy rozwój spółki NEAG poprzez rozbudowę

${ }_{144}$ Tamże, Notariale Gründungsverhandlung betreffend die Niederschlesische Elektrizitäts Aktengesellschaft. Sitz Hirschberg in Riesengebirge [bp.].

145 A. Hoffmann, Rozwój elektryfikacji w Niemczech (od 1884 do 1936 r.), „Przegląd Elektrotechniczny" 1937, z. 3, s. 74, 88-89; G. Siegel, Die Elektrizitätwirtschaft Deutschlands in und nach dem Kriege, „Naturwissenschaften”, t. 8, 1920, s. 519-520. ${ }^{146}$ Landes Archiv Berlin, A rep. 250-03-07, sygn. 240, Konsortialvertrag... [bp.]. 147 Tamże. 
bazy energetycznej w dorzeczu Bobru ${ }^{148}$. Gdy skończyły się możliwości budowy elektrowni przy niezagospodarowanych stopniach wodnych spółka NEAG zaczęła przejmować elektrownie od lokalnych fabrykantów i włączać je do swojego systemu energetycznego.

W miarę uruchamiania kolejnych elektrowni spółka NEAG produkowała coraz więcej energii. W latach 1918-1919 elektrownie firmy wyprodukowały $16,1 \mathrm{mln} \mathrm{kWh}$, w $1922-1923$ było to $27,3 \mathrm{mln} \mathrm{kWh}$, w 19251926 było to już $38 \mathrm{mln} \mathrm{kWh}$ rocznie. Największym odbiorcą był przemysł kupujacy 56\% produkcji, czyli $21,3 \mathrm{mln} \mathrm{kWh}, 14,2 \%(5,394 \mathrm{mln} \mathrm{kWh})$ kupiły różne spółdzielnie i towarzystwa, 11,5 (4,378 kWh) zostało dostarczone do 17 miast, 6\% (2,367 $\mathrm{mln} \mathrm{kWh})$ spożytkowało rolnictwo i kolej, a 5,5\% (2,1 mln kWh) trafiło do 191 zasilanych gmin ${ }^{149}$.

Dzięki dążeniu władz prowincji śląskiej do maksymalnego wykorzystania potencjału energetycznego rzeki Bóbr, Dolny Śląsk (po podziale na Górny i Dolny Ślask w 1919 r.) był liderem w wytwarzaniu energii elektrycznej z wody na tle innych, uprzemysłowionych prowincji pruskich, które miały uregulowane rzeki. W 1938 r. elektrownie wodne wyprodukowały $22,8 \%$ całości energii, podczas gdy w Westfalii energetyka wodna odpowiadała za $12 \%$ produkcji, a w prowincji reńskiej - 5,6\% ${ }^{150}$.

Współpraca wielkiego przemysłu i samorządów odbywała się również w mniejszej skali, powiatowej. Przykładem jest spółka zawiązana przez powiaty środkowego dorzecza Bobru, celem wydajniejszego koordynowania zagospodarowania nadwyżek energii z lokalnych elektrowni przyfabrycznych. Spółka Kommunale Elektricitäts-Lieferungs-Gesellschaft AG Sagan (KELG) powstała w 1922 r. Jej udziałowcami kapitałowymi były Elektrowerke, która w spółce miała 48,6\% akcji, powiaty żagański, szprotawski, kożuchowski i miasto Żagań, które łącznie miały $36,3 \%$ akcji oraz zarząd prowincji śląskiej $(12,13 \%)^{151}$.

KELG integrując lokalnych wytwórców i odbiorców energii podpisała umowy m.in. z elektrowniami na Bobrze przy zakładach młynarskich w Gorzupi Dolnej, fabryką celulozy w Lesznie Górnym, hutą w Małomicach i z elektrownia Saalmanna ${ }^{152}$. Dodatkowej energii dostarczały

148 Tamże.

149 AP Jelenia Góra, AMJG, sygn., 9115, Niederschrift über die 6. Sitzung des Talsperrenbeirates in Hirschberg in Schlesien am 20 October 1926, k. 36.

${ }^{150}$ Statistisches Jahrbuch für das Deutsche Reich 1939, Berlin 1940, s. 192.

${ }_{151}$ Kommunale Elektricitäts-Lieferungs-Gesellschaft Aktiengesselschaft, Sagan, w: Schlesien. Kultur und Arbeit..., s. 251.

${ }_{152}$ Landes Archiv Berlin, A rep. 250-03-07, sygn. 132, Satzung der Kommunale Elektricitäts-Lieferungs-Gesellschaft Aktiengesselschaft, Sagan [bp.]. 
dwie elektrownie na węgiel brunatny w Łazie w powiecie żarskim (6 MW) i niewielka elektrownia przy hucie Henrietty w Przemkowie $(0,8 \mathrm{MW})^{153}$. W 1923 r. do sieci KELG została włączona elektrownia książęca w żagańskim młynie górnym ${ }^{154}$. Jej podstawowym zadaniem było wyrównanie niedoborów energii elektrycznej w powiecie, co spowodowane było częstymi brakami węgla po I wojnie światowej ${ }^{155}$.

KELG nie przyczynił się wydatnie do rozwoju energetyki wodnej nad Bobrem. Jedyną inwestycją KELG na obszarze środkowego dorzecza Bobru była elektrownia wodna w miejscowości Gryżyce, która powstała ze środków żagańskiego magistratu jako elektrownia komunalna i została wniesiona do spółki KELG aportem ${ }^{156}$. Brak większych inwestycji spowodowany był dużym importem taniej energii z Łużyc. Elektrowerke miało w pobliżu Żagania dużą rozdzielnię w Jankowej Żagańskiej, obsługująca powiaty żagański, szprotawski, kożuchowski, gdzie działały przedsiębiorstwa zjednoczone w VIAG ${ }^{157}$.

Największa inwestycja hydroenergetyczna została zrealizowana w dolnym biegu rzeki Bóbr, gdzie obrót energią zdominowany był przez Marchijne Zakłady Elektryfikacyjne (Märkische Elektrizitätswerk AG, MEW). Spółka powołana została w 1909 r. przez AEG, Elektrobank i Zarząd Prowincji Brandenburskiej, który w 1920 r. został większościowym udziałowcem spółki ${ }^{158}$. MEW odznaczała się dużą dynamika przyrostu. Elektrownie MEW w 1910 r. produkowały rocznie $1 \mathrm{mln} \mathrm{kWh}$, a w $1929 \mathrm{r}$. firma ta dostarczała rocznie $500 \mathrm{mln} \mathrm{kWh}$. W tym czasie długość linii wysokiego napięcia wzrosła z $200 \mathrm{~km}$ do ponad $12000 \mathrm{~km}^{159}$. Firma dostarczała energię do $83 \%$ miast i gmin, $89,9 \%$ gmin wiejskich, $79,6 \%$ gospodarstw rolnych i $67,8 \%$ gospodarstw domowych na obszarze objętym koncesja ${ }^{160}$.

${ }^{153}$ Die Elektrizitätswirtschaft im Deutschen Reich. Entstehung, Aufbau, Werke, Arbeits- und Interessengebiete, Statistik, Finanzen, Berlin 1934, s. 334.

154 AP Zielona Góra, Archiwum Książąt Żagańskich, sygn., 795, Niederschrift über die 3. April 1923 auf der Baustelle Sagan Schlossmühle stattgehabte Besprechung, k. 19.

155 Tamże, Erläuterungsbericht zu dem vorläufigen Ausbau, k. 21.

${ }^{156}$ Landes Archiv Berlin, A rep. 250-03-07, sygn. 132, Satzung der Kommunale Elektricitäts-Lieferungs-Gesellschaft Aktiengesselschaft, Sagan [bp.].

${ }_{157}$ Kommunale Elektricitäts-Lieferungs-Gesellschaft Aktiengesselschaftu..., s. 130.

158 Die Elektrizitätswirtschaft im Deutschen Reich..., s. 372.

159 AP Zielona Góra, Wydział Powiatowy w Krośnie, sygn. 199, Märkischen Elektrizitätswerk Aktiengesellschaft Berlin, 21 Geschäftberich für das Geschäftjahr 1929, k. 105-106.

${ }_{160}$ Tamże, Märkischen Elektrizitätswerk Aktiengesellschaft Berlin, 21 Geschäftberich für das Geschäftjahr 1929, k. 387-389; tamżę, Niederschrift über des Aufsichtsrates am Mitwoch, den 11 december 1929, k. 335-345. 
Obsługując wielki system energetyczny, integrujacy wiele miast i fabryk MEW musiała zmagać się ze zmiennymi obciążeniami dobowymi w swojej sieci. Ze względu na fakt, że energii elektrycznej nie da się magazynować, należy zapewnić zwiększona jej podaż w godzinach szczytów energetycznych. Największe zapotrzebowanie na energię szczytowa zgłaszała rozrastająca się aglomeracja Berlina ${ }^{161}$. Aby odpowiedzieć na to zapotrzebowanie, zarząd MEW zdecydował się na budowę elektrowni wodnej szczególnego rodzaju, jakim jest elektrownia szczytowo-pompowa.

Poszukując najlepszej lokalizacji pod tego typu inwestycję, zdecydowano się na dolny bieg Bobru, który był już rzeką uregulowana. Dodatkowo sieć zbiorników zapewniała ochronę przed powodzia i większą stabilność pracy elektrowni w latach suchych, przy w miare równomiernych przepływach, czyniąc inwestycję bardziej opłacalna ekonomicznie ${ }^{162}$.

W 1923 r. Zarząd Prowincji Brandenburskiej podją decyzję o budowie elektrowni. Wówczas też ogłoszono konkurs na projekt elektrowni ${ }^{163}$. W 1928 r. firma Siemens opracowała wstępny projekt zagospodarowania energetycznego dolnego odcinka Bobru, który zainteresował dyrekcję MEW. Jednak projekt budowy wielkiej elektrowni w Dychowie został odłożony ze względu na wielki kryzys, który rozpoczą się w 1929 r. $^{164}$

Do pomysłu realizacji wielkiej inwestycji hydrotechnicznej powrócono po przemianach ustrojowych w Niemczech. W III Rzeszy rozpoczą się okres gigantomanii. Jej przejawem był powrót do planów zabudowy hydrotechnicznej dolnego Bobru jesienia 1933 r. Do roku 1936 powstał cały hydrowęzeł, który obejmował szereg obiektów hydrotechnicznych - m.in. kanał derywacyjny o długości ponad $20 \mathrm{~km}$ i trzy zbiorniki, w tym zbiornik wyrównania szczytowego o pojemności $3,4 \mathrm{mln} \mathrm{m}^{3}$, przy którym powstała elektrownia szczytowo-pompowa w Dychowie o mocy $75 \mathrm{MW}^{165}$.

Rozwój elektrowni szczytowo-pompowych wiązał się z dynamicznym rozwojem elektrowni węglowych, których opłacalność ekonomiczna

${ }^{161}$ H. Pussel, K. Pester, Das Boberkraftwerk, „Siemens Zeitschrift”, 12, 1398, s. 3.

162 G. Warrelmann, Das Boberkraftwerk des Märkischen Elektrizitätswerk AG Berlin, „Elektrotechnische Zeitschrift”, 25, 1938, s. 700.

163 AP Zielona Góra, Wydział Powiatowy w Krośnie, sygn. 199, Betrifft Aubau der Boberwasserkraft bei Deichow durch das Märkischen Elektrizitätswerk, k. 147-148.

${ }_{164}$ Tamże, Niederschrift über des Aufsichtsrates am Mitwoch, den 11 december 1929, k. 331-334.

${ }^{165}$ H. Pussel, K. Pester, dz. cyt., s. 3-4. 
i wydajność doprowadziły do marginalizacji elektrowni wodnych na Ślasku. Tym ostatnim przypadła rola regulacyjna w rozwijajacych się w XX w. systemach energetycznych. Rozwój sieci okręgowych stał się czynnikiem, który nadal energetyce wodnej na Bobrze wymiar ponadregionalny. Gęsta sieć elektrowni wodnych o niedużej mocy przyczyniła się do szybkiej elektryfikacji tego obszaru, a od lat 30. XX w. potencjał energetyczny Bobru przestał służyć jedynie lokalnym odbiorcom, ale zasilał również przemysł i mieszkania $\mathrm{w}$ Berlinie.

\section{Zakończenie}

Dzieje energetycznego wykorzystania rzeki Bóbr sięgają XIII w., gdy Piastowie śląscy sprowadzali osadników z Europy Zachodniej w nadziei ożywienia gospodarczego tego obszaru. Koloniści przynieśli nowe formy uprawy ziemi i narzędzia, w tym młyny wodne, które aż do połowy XIX w. były podstawowym źródłem energii. Oprócz nowych narzędzi osadnicy przynieśli ze sobą nowe wzorce życia społecznego, w tym ideę samorządności miast. Dzięki mocnej pozycji prawnej i ekonomicznej miasta bobrzańskie aż do XVI w. były głównymi ośrodkami wzrostu, gdzie zwiększająca się liczba ludności i rozwój rzemiosła przyczyniały się do rozwoju miejskiego młynarstwa. Pozycja ekonomiczna miast została zachwiana w okresie rządów dynastii habsburskiej, opierającej swą władzę na lokalnej szlachcie, której lojalność była zapewniana licznymi nadaniami ziemskimi. W wyniku rozwoju folwarczno-pańszczyźnianych stosunków gospodarczych ciężar życia gospodarczego począł przenosić się z miast na obszary wiejskie, gdzie dynamicznie rozwijały się młyny zbożowe, papiernicze i kuźnicze. Na ich bazie rozwijały się manufaktury, a w XIX w. młyny wodne zasilały już sporych rozmiarów fabryki i huty. Procesy zapoczątkowane reformami społecznymi, a także rozwojem industrializacji, wysunęły na czoło przemian w energetyce wodnej dorzecza Bobru wielki kapitał, który rozpoczał koncentrację lokalnego przemysłu w spółkach akcyjnych. Ich zaplecze finansowe pozwoliło na modernizację bazy energetycznej fabryk, których podstawowym źródłem zasilania w XIX w. były jeszcze młyny wodne. Na ich bazie w początkach XX w. uruchomiono szereg elektrowni, z których nadwyżki energii zakupywał spółki elektryfikacyjne tworzone przez samorządy we współpracy z wielkim kapitałem przemysłowym. 


\section{Załączniki}

\section{Załącznik 1}

Elektrownie przyfabryczne uruchomione na bazie dawnych młynów w dorzeczu Bobru do 1945 r.

\begin{tabular}{l|l|c|l|c}
\hline \multicolumn{1}{c|}{ Rzeka } & \multicolumn{1}{|c|}{ Miejscowość } & $\begin{array}{c}\text { Rok wstawienia } \\
\text { generatora prądu }\end{array}$ & \multicolumn{1}{c}{ Właściciel } & $\begin{array}{c}\text { Moc turbin } \\
\text { MW }\end{array}$ \\
\hline Bóbr & Nowogród Bobrzańśki & 1894 & $\begin{array}{l}\text { Saalmann Elektrizitätswerke und Naumburger Bobermühlen } \\
\text { Od 1925 Elektrowirtschaft Grünberg G.m.b.H } \\
\text { Od 1927 Märkische Elektrizitätswerk AG }\end{array}$ & 0,66 \\
\hline Kwisa & Świeradów Zdrój & 1900 & b.d. & 0,05 \\
\hline Bóbr & Szprotawa & 1902 & Wodociagi miejskie Szprotawy & b.d. \\
\hline Bóbr & Żagań (młyn dolny) & 1904 & Moses Löw Beer & 1,5 \\
\hline Kamienna & Piechowice & 1905 & $\begin{array}{l}\text { Do 1934 Fabryka Tektury } \\
\text { Od 1934 NEAG }\end{array}$ & 0,736 \\
\hline Bóbr & Dąbrowica & 1908 & Papierfabrik Eichberg & b.d. \\
\hline Bóbr & Małomice & 1910 & Georg Sindermann Internationale Metallwerke & 0,36 \\
\hline Bóbr & Szprotawa & 1910 & Wilhelmshütte Eisen- und Emaillierwerke AG & 0,735 \\
\hline Bóbr & Stara Oleszna & 1910 & $\begin{array}{l}\text { Artur Elsner Kraftwerk } \\
\text { Od 1935 NEAG }\end{array}$ & 1,2 \\
\hline Bóbr & Gorzupia Dolna & 1911 & Schenke- und Hempel Bobermühle und Kraftwerk Nieder Gorpe & 0,67 \\
\hline Kwisa & Kliczków & 1913 & Fürstliche zu Solm'sches Elektrizitätswerk Klitschdorf & 0,08 \\
\hline Kwisa & Zebrzydowa & 1913 & Augustin, Mühle und Elektrizitätswerk Siegersdorf & 0,176 \\
\hline Kamienna & Szklarska Poręba & 1914 & $\begin{array}{l}\text { Do 1934 Fabryka Tektury } \\
\text { Od 1934 NEAG }\end{array}$ \\
\hline Kwisa & Mirsk & 1915 & b.d. & 0,16 \\
\hline Kwisa & Nowogrodziec & 1915 & Elektrizitätswerk Naumburg a/Q & 0,08 \\
\hline
\end{tabular}




\begin{tabular}{|c|c|c|c|c|}
\hline Rzeka & Miejscowość & $\begin{array}{l}\text { Rok wstawienia } \\
\text { generatora prądu }\end{array}$ & Właściciel & $\begin{array}{l}\text { Moc turbin } \\
\text { w MW }\end{array}$ \\
\hline Bóbr & Koniec Świata & 1918 & Papierfabrik Weltende GmbH & 1,36 \\
\hline Kwisa & Ławszowa & 1921 & Fürstliche zu Solm'sches Hüttenwerk Lorenzdorf & b.d. \\
\hline Bóbr & Żagań (młyn górny) & 1923 & Księstwo Żagańskie & 0,7 \\
\hline Bóbr & Pilchowice & 1938 & Holzstoff und Pappenfabrik „Marienthal” & 0,15 \\
\hline Bóbr & Szprotawa & 1938 & Elektrownia przy młynie zbożowym i piekarni (młyn dolny) & 0,06 \\
\hline Kwisa & Świętoszów & 1938 & Schlesische Pappenfabriken AG & 1,38 \\
\hline Kwisa & Osiecznica & 1938 & Schlesische Pappenfabriken AG & 1,36 \\
\hline Bóbr & Leszno Górne & b.d. & $\begin{array}{l}\text { Vereinigte Zellstoff- und Papierfabriken Kostheim-Oberleschen } \\
\text { A.-G., Werk Ober Leschen }\end{array}$ & 0,295 \\
\hline Kwisa & Orłowice & b.d. & Papierfabrik Ullersdorf GmbH & b.d. \\
\hline
\end{tabular}

Źródło: Opracowanie własne 


\section{Załącznik 2}

Nowe elektrownie uruchomione przez spółki elektryfikacyjne w dorzeczu Bobru do 1945 r.

\begin{tabular}{l|l|c|c|c}
\hline \multicolumn{1}{c|}{ Rzeka } & \multicolumn{1}{|c|}{ Miejscowość } & Rok uruchomienia & Właściciel & Moc turbin w MW \\
\hline Kwisa & Leśna & 1907 & NEAG & 2,6 \\
\hline Bóbr & Siedlęcin & 1910 & NEAG & 0,312 \\
\hline Bóbr & Pilchowice & 1911 & NEAG & 7,5 \\
\hline Bóbr & Gryżyce & 1922 & KELG & 3,168 \\
\hline Kwisa & Złotniki & 1924 & NEAG & 4,4 \\
\hline Bóbr & Siedlęcin & 1925 & NEAG & 2,4 \\
\hline Bóbr & Nielestno & 1927 & NEAG & 0,8 \\
\hline Bóbr & Wrzeszczyn & 1927 & NEAG & 4,79 \\
\hline Bóbr & Kraszewice & 1932 & NEAG & 0,96 \\
\hline Bóbr & Włodzice Małe & 1935 & MEAG & 1 \\
\hline Bóbr & Raduszec Stary & 1935 & MEW & 2,98 \\
\hline Bóbr & Dychów & 1936 & & 75
\end{tabular}

Źródło: Opracowanie własne 


\section{Załącznik 3}

Zestawienie wzmianek dotyczacych wykorzystania wybranych stopni wodnych

\begin{tabular}{|c|c|c|c|c|c|}
\hline Rzeka & Miejscowość & $\begin{array}{c}\text { Lokalizacja } \\
\text { młyna }\end{array}$ & $\begin{array}{l}\text { Data pierw- } \\
\text { szej wzmianki }\end{array}$ & $\begin{array}{l}\text { Wzmiankowany } \\
\text { użytkownik stopnia }\end{array}$ & $\begin{array}{c}\text { Wzmiankowane przeznaczenie } \\
\text { młyna }\end{array}$ \\
\hline Bóbr & Wleń & $\begin{array}{l}\text { Lähnmühle } \\
\text { (Młyn dolny) }\end{array}$ & 1217 & $\begin{array}{l}1217 \text { - Henryk Brodaty } \\
1345 \text { - wójt dziedziczny } \\
1371 \text { - Bernhard von Zedlitz } \\
1438 \text { Petsche von Zedlitz } \\
1442 \text { - rada miejska Wlenia } \\
1598 \text { - Konrad von Zedlitz } \\
\text { XVIII w. rodzina Ander } \\
1928 \text { - Eduard Ander }\end{array}$ & $\begin{array}{l}1217 \text { - młyn zbożowy } \\
1345-\text { zbożowy, foluszniczy } \\
1371 \text { - zbożowy, foluszniczy } \\
1438 \text { - zbożowy, tartaczny, dębny } \\
1442 \text { - zbożowy, tartaczny, dębny } \\
1598 \text { - zbożowy, tartaczny } \\
\text { XVIII w. - zbożowy, tartaczny } \\
1928 \text { - zbożowy, tartaczny, ścieralnia } \\
\text { drewna }\end{array}$ \\
\hline Bóbr & Nowogród & $\begin{array}{l}\text { Jaz za } \\
\text { mostem na } \\
\text { lewym brzegu } \\
\text { rzeki }\end{array}$ & 1353 & $\begin{array}{l}1353 \text { - klasztor Augustianów } \\
1570 \text { - rada miejska Nowogrodu Bobrzań- } \\
\text { skiego } \\
1894 \text { - Hermann Saalmann }\end{array}$ & $\begin{array}{l}1353 \text { - zbożowy } \\
1570 \text { - zbożowy } \\
1894 \text { - elektrownia }\end{array}$ \\
\hline Bóbr & Żagań & $\begin{array}{l}\text { Młyn dolny } \\
\text { przy bramie } \\
\text { żarskiej }\end{array}$ & 1334 & $\begin{array}{l}\text { Przed } 1334 \text { - Henryk IV Wierny } \\
1334 \text { - klasztor Augustianów } \\
1482 \text { - książę saski Ernst } \\
1549 \text { - Maksymilian II Habsburg } \\
1601 \text { - rada miejska Żagania } \\
\text { Przed } 1858 \text { - Theodor Strahl i Leonor } \\
\text { Reichenheim } \\
1858 \text { - księżna żagańśka Dorota Talleyrad } \\
1904 \text { - Moses Low Beer }\end{array}$ & $\begin{array}{l}1334 \text { - zbożowy, słodowy } \\
1482 \text { - kuźniczy } \\
1601 \text { - białoskórniczy, dębny, foluszni- } \\
\text { czy, prochowy } \\
1794 \text { - kuźniczy } \\
1821 \text { - dębny, kuźniczy, białoskórni- } \\
\text { czy, tkalniczy, garbarski } \\
1904 \text { - elektrownia }\end{array}$ \\
\hline Bóbr & Żagań & $\begin{array}{l}\text { Młyn górny } \\
\text { przy bramie } \\
\text { szprotawskiej }\end{array}$ & 1450 & $\begin{array}{l}1450 \text { - Rudolf żagański } \\
1601 \text { - rada miejska Żagania } \\
\text { XIX w. - Księstwo Żagańskie }\end{array}$ & $\begin{array}{l}1410 \text { - zbożowy } \\
1472 \text { - szlifirerski } \\
1845 \text { - zbożowy, tartaczny } \\
1923 \text { - elektrownia }\end{array}$ \\
\hline
\end{tabular}




\begin{tabular}{|c|c|c|c|c|c|}
\hline Rzeka & Miejscowość & $\begin{array}{c}\text { Lokalizacja } \\
\text { mlyna }\end{array}$ & $\begin{array}{l}\text { Data pierw- } \\
\text { szej wzmianki }\end{array}$ & $\begin{array}{l}\text { Wzmiankowany } \\
\text { użytkownik stopnia }\end{array}$ & $\begin{array}{l}\text { Wzmiankowane przeznaczenie } \\
\text { młyna }\end{array}$ \\
\hline Bóbr & Małomice & $\begin{array}{l}\text { Młyn kuźni- } \\
\text { czy na mły- } \\
\text { nówce }\end{array}$ & 1560 & $\begin{array}{l}1560 \text { - Fabian Schönaich } \\
1717 \text { - hrabiowie von Redern } \\
1798 \text {-hrabiowie von Dohna } \\
1871 \text { - Schuster-Bank Berlin } \\
1898 \text { - Internationale Metallwerke } \\
1910 \text { - Internationale Metall - Werke Georg } \\
\text { Sindermann }\end{array}$ & $\begin{array}{l}1560 \text { - kuźniczy } \\
1717 \text { - kuźniczy } \\
1798 \text { - kuźniczy } \\
1871 \text { - kuźniczy } \\
1910 \text { - elektrownia }\end{array}$ \\
\hline Bóbr & Bolesławiec & Młyn górny & 1260 & $\begin{array}{l}1260 \text { - dobra zamkowe (Konrada I Głogow- } \\
\text { skiego) } \\
1506 \text { - dobra królewskie (Władysława Jagiel- } \\
\text { lończyka) } \\
1594 \text { - rada miejska Bolesławca } \\
1750 \text { - rada miejska Bolesławca } \\
1813 \text { - Friedrich Gläser } \\
1871 \text { - Samson Woller }\end{array}$ & $\begin{array}{l}1260 \text { - zbożowy } \\
1560 \text {-zbożowy } \\
1594-\text { zbożowy } \\
1750 \text { - zbożowy, tartaczny } \\
1813 \text { - zbożowy, tartaczny, białoskór- } \\
\text { niczy - przędzalniczy } \\
1871 \text { - }\end{array}$ \\
\hline
\end{tabular}

Źródło: Opracowanie własne. 


\section{Bibliografia}

Afeltowicz T., Studia nad historia banków ślaskich (do roku 1918), WrocławWarszawa-Kraków 1963.

Althans E., Mittel und Wege um von den Gebirgsflüssen Schlesiens zunächst den Queis und Bober nicht nur unschädlich, sondern für Land und Leute, besonders auch für die Schiffhart in Schlesien volkswirtschaftlich nutzbar zu machen. Vortrag am 6. Juli 1896 beim 30. Schles. Gewerbetag in Löwenberg, Breslau 1896.

Baranowski B., Polskie mlynarstwo, Wrocław-Warszawa-Kraków-Gdańsk 1977.

Bergemann J.G., Chronik der Stadt Bunzlau. Erste Abtheilung, Bunzlau 1829. Boryna M., Małomice na rubieży Borów Dolnoślaskich, Żary 2008.

Buczek K., Z dziejów mtynarstwa w Polsce średniowiecznej, „Studia Historyczne", t. 12, 1969.

Bujkiewicz Z., Krajobraz materialny i społeczny Zielonej Góry od końca XVIII do połowy XX wieku. Przestrzeń - ludność - gospodarka, Zielona Góra 2003.

Czapliński M., Dzieje Ślaska od 1806 do 1945 roku, w: Historia Ślaska, red. M. Czapliński, Wrocław 2002.

Dembińska M., Przetwórstwo zbożowe w średniowiecznej Polsce (X-XIV wiek), Wrocław-Warszawa-Kraków-Gdańsk, 1973.

Die Elektrizitätswirtschaft im Deutschen Reich. Entstehung, Aufbau, Werke, Arbeits- und Interessengebiete, Statistik, Finanzen, Berlin 1934.

Dlugos J., Chronik der Propstei Naumburg am Bober, Grünberg 1926.

Fechner H., Geschichte des Schlesischen Berg- und Hüttenwesens in der Zeit Friedrich's des Grossen, Friedrich Wilhelm's II. und Friedrich Wilhelm's III. 1741 bis 1806, t. 2, Berlin 1903.

Eisenmänge J.T., Der Kreis Hirschberg. Seine Natur, Industrie, Bewohner, Verwaltung und Ortschaften. Ein Handbuch für Freunde des Riesengebirges und der Heimathskund, Hirschberg 1879.

Frančić M., Technika mtynów wodnych w Polsce w XVI i XVII w., „Kwartalnik Historii Kultury Materialnej”, 2, 1954, nr 1-2.

Glied R., Mallmitz, Kreis Sprottau in Niederschlesien, Egelsbach 1984.

Gross A., Heimatbuch des Kreises Löwenberg in Schlesien, wyd. 2., Löwenbergs 1925 .

Heinrich A., Geschichte der Fürstentums Sagan bis zum Ende der säschischen Herrschaft im Jahre 1549, Sagan 1911.

Heinrich A., Geschichtliche Nachrichten über Naumburg am Bober, Freiwaldau und Halbau aus den Quellen zusammengestellt, Sagan 1900.

Herbst J.K., Chronik der Stadt Hirschberg in Schlesien bis zum Jahre 1847, Hirschberg 1849.

Hoffmann A., Rozwój elektryfikacji w Niemczech (od 1884 do 1936 r.), „Przegląd Elektrotechniczny" 1937, z. 3.

Hughes T.P., Networks of Power. Electrification in Western Society 1880-1930, Baltimore 1983. 
Intze O., Bericht über die Wasserverhältnisse der Gebirgsflüsse Schlesiens im Bober- und Queissgebiete sowie im Gebiete der Glatzer Neisse und deren Verbesserung zur Ausnutzung der Wasserkrafte sowie zur Verminderung der Hochwasserschaden durch Anlage von Sommelbecken, Berlin 1899.

Januszewski S., Elektrownie wodne doliny Bobru, w: Zabytki przemystu i techniki w Polsce, t 6: Dzieła techniki - dobra kultury, red. S. Januszewski, Wrocław 2002.

Knie J.G., Alphabetisch-statistich-topographische Ubersicht der Dorfer, Flecken, Stadte und andern Orte der Konigl. Preuss. Provinz Schlesien, Breslau 1845.

Knoblich A., Chronik von Lähn und Burg Länhaus am Bober. Urkundliche Beiträge zur Geschichte der Städte, Ritterburgen, Fürsten, und Adelsgeschlechter Schleseins, Breslau 1863.

Kouschil Ch., Mtynarstwo a rozwój społeczny w średniowieczu, w: Niebezpieczne drogi $i$ podejrzani młynarze, przeł. Z. Czarnuch, Gorzów Wielkopolski 2000.

Kubicki R., Sieć mtynów wodnych w dobrach klasztornych na Pomorzu Wschodnim w XIII-XVI w., „Hereditas Monasteriorum”, t. 2, 2013.

Kuczer J., Szlachta $w \dot{z} y c i u$ społeczno-gospodarczym księstwa głogowskiego w epoce habsburskiej 1526-1740, Zielona Góra 2007.

Kunick E., Heimatbuch des Kresises Landeshut in Schlesiens, t. 1, Landeshut 1929.

Kwaśny Z., Mtyny zbożowe w dobrach Schaffgotschów na poczatku XVIII wieku, „Ślaski Kwartalnik Historyczny Sobótka” 1959, nr 4.

Leipelt A., Geschichte der Stadt und Herzogtums Sagan, Sorau 1853.

Ładogórski T., Generalne tabele statystyczne Śląka 1787 roku, Wrocław 1954.

Łuczak Cz., Dzieje gospodarcze Niemiec 1871-1945, Poznań 1984.

Maleczyńska K., Dzieje starego papiernictwa ślaskiego, Wrocław-WarszawaKraków 1961.

Matuszkiewicz F., Historia Szprotawy, tłum. J. Kuczer, Szprotawa 2010.

Perschke W., Beschreibung und Geschichte der Stadt Landeshut in Schlesien als Beitrag zur Verfassung-Geschichte deutscher Städte, Landeshut 1829.

Pobóg-Lenartowicz A., Kanonicy regularni a miasto na przykładzie Żagania, $\mathrm{w}$ : Klasztor $w$ mieście średniowiecznym $i$ nowożytnym, red. M. Derwich, A. Pobóg-Lenartowicz, Wrocław-Opole 2000.

Popiołek K., Historia Ślaska. Od pradziejów do 1945 roku, Katowice 1972.

Popiński K., Życie gospodarcze w latach 1806-1945, w: Bolesławiec. Zarys monografii miasta, red. T. Bugaj, K. Matwijowska, Wrocław-Bolesławiec 2001.

Pussel H., Pester K., Das Boberkraftwerk, „Siemens Zeitschrift”, 12, 1398.

Reynolds T., Stronger than a Hundred Men. A History of the Vertical Water Wheel, Baltimore-London 1983.

Saalmann H., Elektricitätswerke Eichdorf- Grünberg, w: Schlesien. Kultur und Arbeit einer deutschen Grenzmark, red. B. Salomon, E. Stein, Berlin 1926. 
Samsonowicz H., Rzemiosto wiejskie w Polsce XIV-XVI wieku, Warszawa 1954.

Sawicka J., Abramowicz Z., Osiecznica. Dzieje zielonej gminy, Suwałki 2010.

Schönberg A., Glunk E., Landes-Elektrizitätswerke, München-Berlin-Oldenbourg, 1926.

Siegel G., Die Elektrizitätwirtschaft Deutschlands in und nach dem Kriege, „Naturwissenschaften”, t. 8, 1920.

Siegel G., Die öffentliche Elektrizitätsversorgung Deutschlands, „Die Naturwissenschaften" 1917, no. 42.

Sowina U., Woda i ludzie w mieście późnośredniowiecznym i wczesnonowożytnym, Warszawa 2009.

Statistisches Jahrbuch für das Deutsche Reich 1939, Berlin 1940.

Stelmach R., Archiwum dokumentów miasta Jeleniej Góry, „Rocznik Jeleniogórski”, t. 40, 2008.

Stelmach R., Cieplice $w$ XIII w. - nieudane fundacje augustiańska $i$ joannicka, „Rocznik Jeleniogórski”, t. 32, 2000.

Stelmach R., Dokumenty do dziejów klasztoru benedyktynek w Lubomierzu, „Rocznik Jeleniogórski”, t. 37, 2005.

Stelmach R., Dzieje klasztoru Magdalenek w Nowogrodźcu nad Kwisq w świetle zachowanych dokumentów, „Rocznik Jeleniogórski”, t. 30, 1998.

Stelmach R., Poczatki prepozytury cystersów krzeszowskich $w$ cieplicach, „Rocznik Jeleniogórski”, t. 34, 2002.

Stelmach R., Posiadtości klasztoru krzeszowskiego w miastach ślaskich na podstawie zachowanych dokumentów w Archiwum Państwowym we Wroctawiu, w: Klasztor $w$ mieście średniowiecznym i nowożytnym, red. M. Derwich, A. Pobóg-Lenartowicz, Wrocław-Opole 2000.

Szczerepa W., Zarys historii Jeleniej Góry od XIV do XX wieku, w: Z historii Jeleniej Góry i regionu, red. K. Kułakowska, Jelenia Góra 2012.

Szymczyk M., Dzieje jeleniogórskiego ośrodka przemystu papierniczego (cz. I do 1945 roku), „Rocznik Jeleniogórski”, t. 33, 2001.

Trawkowski S., Młyny wodne w Polsce w XII wieku, „Kwartalnik Historii Kultury Materialnej”, 7, 1959, nr 1.

Tschoppe G.A., Stenzel G.A., Urkundensammlung zur Geschichte des Ursprungs der Städte und der Einführung und Verbreitung deutscher Kolonisten und Rechte in Schlesien und der Ober-Lausitz, Hamburg 1832.

Urbarz Janowic Wielkich, w: Urbarze ślaskie z końca XVIII wieku, oprac. K. Orzechowski, Z. Szkurłatowski, Wrocław-Warszawa-Kraków 1961.

Warrelmann G., Das Boberkraftwerk des Märkischen Elektrizitätswerk AG Berlin, „Elektrotechnische Zeitschrift” 1938, nr 25.

Wasiutyński W., Regal młynny w średniowiecznym prawie polskim, Warszawa 1936.

Wąs G., Dzieje Ślaska od 1526 do 1806 roku, w: Historia Ślaska, red. M. Czapliński, Wrocław 2002.

Wereszczyński W., Powstanie i lokacja Jeleniej Góry na prawie miejskim, „Rocznik Jeleniogórski”, t. 40, 2008. 
Wereszczyński W., Proces rozbudowy majatku Gotsche II Schoffa, założyciela rodu z Chojnika i Gryfa, cz. 2, „Rocznik Jeleniogórski”, t. 35, 2003, s. $41-154$.

Wernicke E., Chronik der Stadt Bunzlau von den Altesten Zeiten bis zur Gegenwart, Bunzlau 1884.

Werth P., Die Handelskammer zu Hirschberg in Schlesien 1850-1900. Ein geschichtlicher Rückblick, Hirschberg 1900.

Witruwiusz, O architekturze ksiag dziesięć, Warszawa 1999.

Żuk L., Z dziejów miasta Jelenia Góra. Mons Cervi - Hirschberg, Jelenia Góra 2013.

Wiktor Krajniak

Between milling and electrification.

Social and economic conditions for exploiting the energy potential of the Bóbr River from the Middle Ages until 1945

(Summary)

The paper presents main hydropower development trends on the Bóbr River between the $13^{\text {th }}$ and the $20^{\text {th }}$ century. Particular focus is placed on the significance of hydropower in the process of advancement of civilisation in the area in question, starting from the mechanisation of production in medieval workshops down to the electrification of industry, agriculture, and towns thanks to power plants established on the basis of old mills. This evolution is traced with the use of archival sources, local chronicles, and secondary sources. They serve as the source of information on the social conditions and economic factors which influenced the evolution of individual mills into modern power plants on the Bóbr River.

Wiktor Krajniak - absolwent historii, filozofii i politologii; w 2016 r. obronił pracę doktorską na Uniwersytecie Zielonogórskim (tytuł rozprawy: „Rozwój energetyki wodnej na rzece Bóbr w XX wieku"). Do zainteresowań badawczych autora należy filozofia nauki i historia gospodarcza, ze szczególnym uwzględnieniem okresu industrializacji i rewolucji naukowo-technicznej. E-mail: wiktor-krajniak@gmail.com. 